\title{
TRANSLATING INDIGENEITIES
}

\section{Educative encounters in Talamanca, Tromsø, and elsewhere}

\author{
Bjørn Ola Tafjord
}

"To me, this is not religion. It is more like a juridical system". Heidi Mayorga Escalante took me aside and lowered her voice. Heidi is the Bribri lawyer and activist who in January 2018 guided our group of researchers at the National Museum of Costa Rica. We had just entered a room where 'INDIGENOUS RELIGION' was written with bold and large letters on one wall, and 'THE CATHOLIC CHURCH' with equally bold and large letters on the opposite wall. Glass boxes with select objects, accompanied by snippets of text, representing indigenous religion and Catholicism respectively, stood on each side of the room, creating a neat symmetry, gesturing a comparison. Heidi was referring to the assemblage of objects and texts that articulated, exhibited, and explained an indigenous religion.

In her view, these objects and the practices and specialists mentioned in the texts did not constitute a religion. The museum had got it wrong. When I asked her to lead us here, both as an expert and as a representative of a community who sees itself as the proper owner of many of the objects kept in the museum, I had told her that we were particularly interested in indigenous religions, that this is what our joint research project focuses on. Was she indirectly saying that we were wrong too? She confessed, quietly, that she had read up on the topic in preparation for our visit. She said she had learnt a lot from doing that, and thanked me for the invitation that had incited her to do so, but she could not agree with how all these authors - anthropologists, archaeologists, historians, and sociologists - present her community and culture as pervaded by an indigenous religion. ${ }^{1}$

With that said, she turned her attention back to the group and clearly asserted that the objects in the glass boxes and the practices they have been part of are very indigenous and priceless to the indigenous communities. Unfortunately, she added, many items like these now dwell in faraway museums and illegal private collections, instead of in the indigenous communities where they belong. She was making these authoritative claims both as a Bribri and as a scholar of law. Her eyes 


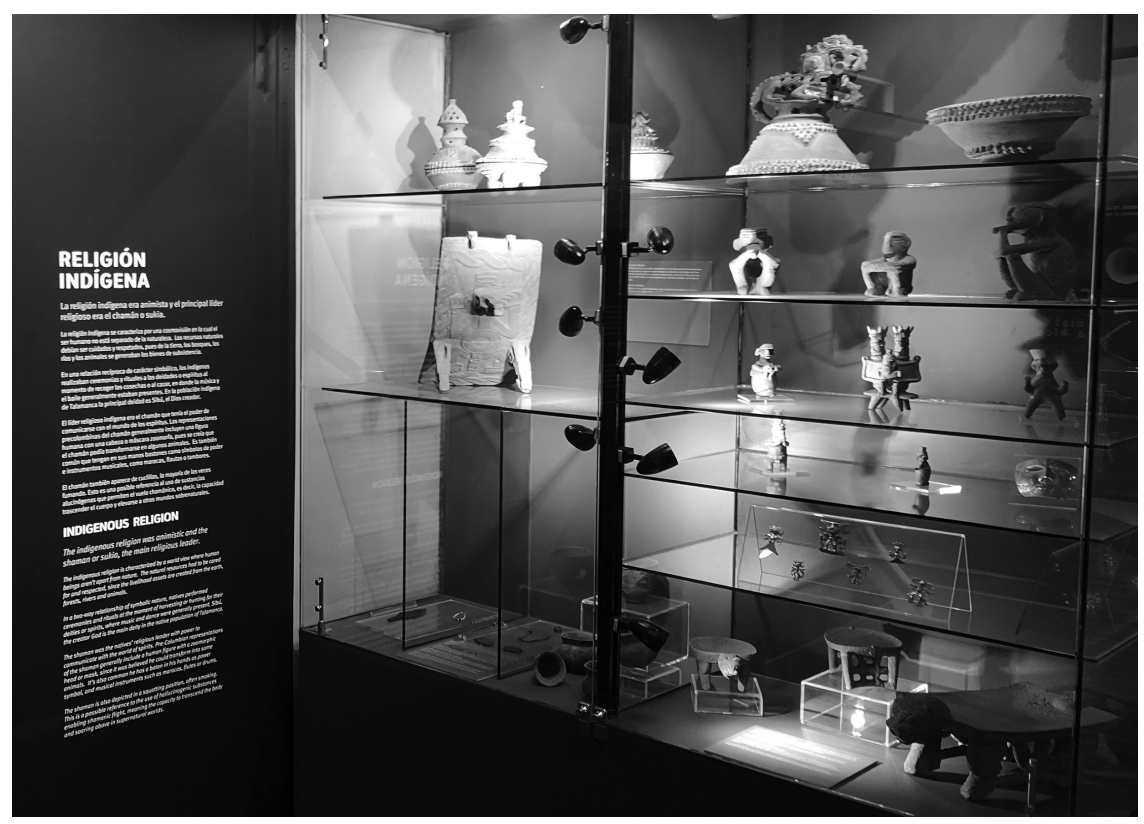

(a)

FIGURE 1.1-1.3 The exhibition of indigenous and Catholic religion, side by side, in the National Museum of Costa Rica. The text on the wall describes the indigenous religion very much in line with old theoretical presumptions about animism and shamanism.

sought Arkotong Longkumer, who nodded in approval. She had been very pleased to learn that he is indigenous too, and of a tiger clan, like herself. Greg Johnson gently offered to put her in contact with people in Hawai' $i$ and Colorado who have experiences with repatriation processes. We then moved to the next room.

That afternoon we went on to visit the Pre-Columbian Gold Museum and dine at a touristy restaurant, while Heidi continued to tell us about the situations for indigenous peoples in her country. She spoke especially about Talamanca, the territory she grew up in and where most of her relatives live. We were all set to travel there in a few days. Heidi told us about things we would see, hear, and otherwise sense in Talamanca, as opposed to here, in the capital San José. She was alerting us to differences and particularities, including divergent conceptions of indigeneity and religion. What she shared with us, and her presence alongside her Chilean husband and their young son, complicated and disturbed the stories that the museums and other powerful actors in this city otherwise convey stories that tend to relegate the indigenous population to a bygone time and to marginal spaces, and that religionise, primitivise, homogenise, and other them.

Heidi's interventions made it evident that we are partaking in multiple and sometimes contradictory didactic exchanges: with indigenous experts, with other academics, with each other, with communities, with places, with institutions, 


\section{INDIGENOUS RELIGION}

\section{The indigenous religion was animistic and the shaman or sukia, the main religious leader.}

The indigenous religion is characterized by a world view where human beings aren't apart from nature. The natural resources had to be cared for and respected, since the livelihood assets are created from the earth, forests, rivers and animals.

In a two-way relationship of symbolic nature, natives performed ceremonies and rituals at the moment of harvesting or hunting for their deities or spirits, where music and dance were generally present. Sibú, the creator God is the main deity in the native population of Talamanca.

The shaman was the natives' religious leader with power to communicate with the world of spirits. Pre-Columbian representations of the shaman generally include a human figure with a zoomorphic head or mask, since it was believed he could transform into some animals. It's also common he has a baton in his hands as power symbol, and musical instruments such as maracas, flutes or drums.

The shaman is also depicted in a squatting position, often smoking. This is a possible reference to the use of hallucinogenic substances enabling shamanic flight, meaning the capacity to transcend the body and soaring above in supernatural worlds.

(b)

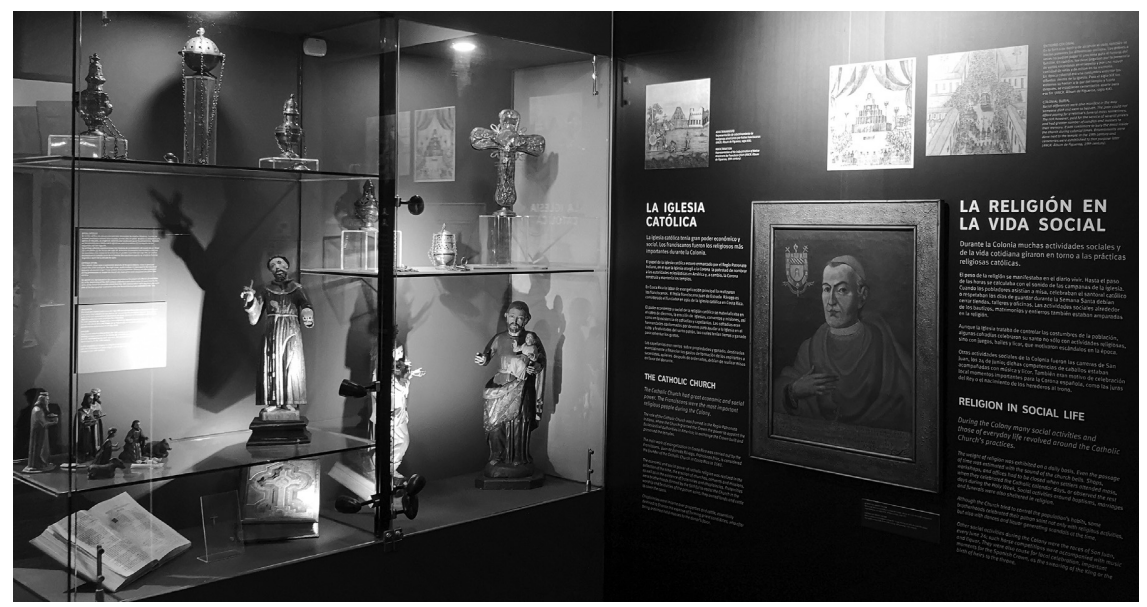

(c)

FIGURE 1.1-1.3 (Continued) 
with objects and exhibitions, and with words and stories. Translations and comparisons are at the heart of all these interactions, suggesting certain identities and relationships, or unsettling them. They are at once pedagogical, political, and analytical.

Over many years, as I have been travelling between Talamanca in the south of Costa Rica and Tromsø in the north of Norway, I have learnt how conceptions of indigeneity and indigenous religions differ in these two places. I have also learnt how helpful it is for the detection of such differences to work in more than one place where articulations of indigeneities and indigenous religions abound. In Talamanca, I do research with Bribris who teach me about their history and society, including their indigeneities and religions. In Tromsø, I teach religious studies in an environment where Sámis in particular, but also members of other indigenous peoples, have a strong presence. On a few occasions, I have organised or co-organised workshops that have brought together representatives of indigenous peoples and researchers from Costa Rica, Norway, and other places. Lately, I have also had the privilege to visit indigenous communities in Nagaland and Hawai' $i$ together with colleagues in the collaborative research project Indigenous Religion(s): Local Grounds, Global Networks (INREL). ${ }^{2}$

This chapter focuses on encounters that have revealed to me and to other participants in them how there are different notions of indigeneity and indigenous religions circulating. These encounters also illustrate how efforts are made to translate and compare distinct people and practices, through recognisable gestures and common concepts such as indigeneity and indigenous religion, in order to suggest similarities or stress specialness. ${ }^{3}$ Based on what I have learnt from these encounters, I argue that it is enlightening to think of indigeneity and indigenous religion as methods. Indigeneity and indigenous religion are conceptual tools with which people do things. They are employed to make understandable, to make relevant, and to shed a sharper light on who some people are in relation to other people, and what some practices are in relation to other practices. In other words, they are used at once pedagogically, politically, and analytically. This is done both by scholars and others. ${ }^{4}$

My approach brings to the fore operations and processes similar to the ones that the anthropologists Mario Blaser and Marisol de la Cadena $(2017,2018)$ call 'commoning', which imply translating someone or something into a subject or entity that is recognisable to more parties, a process which also entails the outlining of a shared domain, and a scaling of the thereby constituted community. This, Blaser and de la Cadena argue, should ideally be done through 'controlled equivocations', a concept of translation they borrow from fellow anthropologist Eduardo Viveiros de Castro (2004), in order not to lose sight of and rule out the 'uncommons', divergent subjects or entities involved in the translation but familiar to only some of the parties. ${ }^{5}$

In the encounters that I describe in this chapter, if we apply this perspective, we witness how indigeneities and indigenous religions become actualised 
in acts of commoning, or through translations of 'uncommon' identities and practices, which also emerge and are affected in the encounters, but whose properties and worlds exceed that which is carried across in the translations (cf. de la Cadena 2015, 2018). In some of the encounters we also witness how indigeneity or indigenous religion is contested through acts of uncommoning, and alternative commoning, like Heidi's "this is not religion" but "more like a juridical system". Indigeneity and indigenous religion can thus be grasped and ungrasped as subjects or entities, as shared domains, and as scaled communities, in addition to being methods. And they can be seen as methods of their own making, since long found in an arsenal available to non-academic and academic actors alike. Examples provided in this chapter, and in the other chapters of this book, show that non-academic actors - especially but not only those who somehow self-identify as indigenous - often make strong and highly conscious efforts to control the equivocations that their own and others' pedagogical, political, and analytical translations necessarily bring about.

In what follows, I will describe some of the events that have made me aware of these issues. Through descriptions of episodes, some from moments when I did not recognise that I was doing fieldwork, others from moments when I did not realise that I was doing more than fieldwork, I try to highlight complexities, reflexivities, frictions, and fusions that characterise and challenge exchanges in our field of study. Of this book's orienting themes, translation and comparison are most salient in this chapter, although it also addresses performances, media and technologies, and sovereignty.

\section{Encountering Talamanca}

When I first went to Talamanca, on the border between Costa Rica and Panama, almost 20 years ago, my ambition was to study the roles of religions among the Bribri, a people who self-identify also as ditsöwö and skowak (in Bribri), as indios and indígenas (in Spanish), and as indigenous (in English). ${ }^{6}$ To my surprise, most residents in Barrio Escalante, the neighbourhood where I ended up staying, claimed that the Bahá'í Faith was their religión indígena or indigenous religion. It is a religion for indigenas all over the world, they explained. Many added that, in the future, because of their spirituality and experience with suffering, the indigenas will illuminate all of humankind. ${ }^{7}$

The elders in Barrio Escalante had become Bahá'í in the 1960s. Nicaraguan and North American 'pioneers' (Bahá'ís insist they have no missionaries) then came to Talamanca to introduce this religion that had begun as a Shia Islamic millenarian movement in Persia and the Ottoman Empire in the mid-19th century. ${ }^{8}$ Although all Bribri Bahá'ís also recognised it as an exogenous and new religion, most of those who I spoke with presented it as another version of their tradiciones indigenas (Sp. 'indigenous traditions'). According to Bribri history, Sibö - the akeköl (Br.) or progenitor and guardian of the Bribri, and the protagonist in the creation of the world in which we live - taught the very first generation of Bribris, who were also the very first human beings, all they needed to 
know. ${ }^{9}$ Applying the basic Bahá'i (and Islamic) doctrine about successive messengers from one God, residents of Barrio Escalante avowed that Sibö was the very first of the messengers from God, while Bahá'u'lláh, the founder of the Bahá'i Faith, was the latest. Their Bahá'i Faith, many told me, was not only compatible with their indigenous traditions but also reinstalling and reinforcing them.

Nevertheless, on most occasions, Bribris would stress that their indigenous traditions should not be mistaken for a religion. Christian Bribris, who are the majority in other parts of Talamanca, have also taken this stance. To Bribri youngsters, and to me, the elders have repeatedly explained how religions are important but limited and largely optional sets of teachings and practices, whereas the indigenous traditions are fundamental since they pertain to everything and are impossible to opt out of for Bribris. Confidently they have declared that the Bribri never had a religion before they began to adopt and adapt Bahá'í or Christian teachings and practices that foreigners brought to Talamanca two generations ago. Before this, they did not need religion, they assert, because the ancestors knew and lived in accordance with 'the law of Sibö' or 'the law of God' (for a fuller account, cf. Tafjord 2004, 2006).

Bribris consistently present themselves as a sovereign people with a sovereign territory. From their perspective, the Costa Rican state, like the Spaniards before it, is an intruder. At the same time, they do have a strong identity as Costa Ricans, but as the original citizens of this land. They see themselves as continuing a five-centuries-long resistance. Their history and the enduring conflicts with colonisers constitute an axis that strongly contributes to shaping their perceptions of themselves. It forges a dichotomy between an unremittingly autonomous 'We' and a continuously threatening 'Other' - ditsöwö, skowak, indios or indígenas versus sikuapa (Br.) or blancos (Sp.).

The concepts that Bribris use to identify and classify themselves imply different scales. They denote what we might think of as particular indigeneities within or across other indigeneities. Ditsöwö (Br. literally 'seed') refers to their internal matrilineal kinship structure and the distribution of clanes (Sp. 'clans') and their lands, a relational and geographical order that also includes the Cabécar, with whom the Bribri share many traditions, institutions, and bordering territories (cf. Bozzoli 1979). Skowak, indio, and indígena are statuses that Bribris attribute to a much broader set of peoples, like the eight officially recognised pueblos indígenas or indigenous peoples in Costa Rica (Bribri, Brunca, Cabécar, Chorotega, Huetár, Maleku, Ngäbe, and Teribe), and comparable peoples elsewhere in the Americas, and sometimes even - although only as indígenas, not as skowak or indios - comparable peoples globally (Tafjord 2016b).

According to Bribri history, that is, history told authoritatively by Bribris, Talamanca has never been conquered by outsiders. But there have been many struggles, including periods of widespread violence and warfare. Foreigners have persistently tried to take control over the territory and the people and extract 
their resources. The Bribris have always resisted and, in the end, expelled the intruders. Historical enquiries by academics largely confirm this narrative.

Spaniards first arrived in 1502, but they never got a lasting foothold in Talamanca (Solórzano 2013; cf. Boza 2014). Franciscan missionaries operated in the area during most of the 17th century, but were driven out in 1709, when Pabru Presbere, who has become a heroic symbol of Talamancan autonomy, led military forces against all colonial installations. The violence unleashed in confrontations between Spaniards and Talamancans was often fierce. The indigenous resistance, aided by the rugged terrain and the climate, and the territory's peripheral location in the colonial geopolitical ordering of the new world, made Talamanca a refuge for diverse people running away from persecution in surrounding regions, but this also created conflicts between indigenous groups. Catholic clergy did not return to Talamanca till the 1880 s, when a period with sporadic missionary incursions began (Drüg 1995). This represented and coincided with state initiatives to take control of the region. The first decades of the 20th century witnessed a violent, government sanctioned, occupation of the Talamanca valley by the United Fruit Company, which made the majority of Bribris retreat temporarily up into the higher mountains. ${ }^{10}$ Today Bribris recount how the useköl, who in the academic literature is often translated as 'the highest religious authority' of the Talamancans (Bozzoli 2006), evicted the banana company by sending floods to destroy its plantations, houses, bridges, and railways. Bribris had barely begun to resettle in the valley in the early 1960s when Mennonite, Catholic, and Bahá'í envoys arrived and settled in different locations where they founded new religious congregations (Drüg 1995; Rojas 2009; Tafjord 2004).

In the 1970s, the current Costa Rican system of indigenous territories or reserves was established, alongside the system of national parks, which put severe restrictions on lands used by indigenous communities. With the Ley Indigena or Indigenous Act, the state created a legal framework which continues to regulate what it means to be indigena and what the properties of the indigenous communities are in the eyes of the Republic. ${ }^{11}$ At about the same time, the first schools in Talamanca were opened by the Catholic missionaries (Drüg 1995). Costa Rica is a confessional Catholic state, and this has been reflected in most of its institutions as they have entered Talamanca. In the 1980s, the national oil company, RECOPE, was met with strong protests when it drilled exploratory wells in Talamanca (Borge and Villalobos 1994). The 1990s saw an influx of NGOs and development projects (Borge and Castillo 1997). In 1993, Costa Rica ratified the ILO Convention 169, which represented an international recognition of indigenous communities and their rights, but the story in Talamanca is that this hardly changed anything in practice.

I have been back in Talamanca several times after the initial fieldwork in 2000 and 2001. ${ }^{12}$ What began as an ethnographic exploration of a particular moment has become a longitudinal study of recent history. Over the years, I have heard numerous accounts about illegal mining and looting of graves and other sites which Bribris often call sitios sagrados (Sp. 'sacred sites'). They have fought 
this for centuries and continue today. Drug trafficking is a new and growing problem, which has made Bribris permit the establishment of a local police force, and thereby another powerful state presence. Since the turn of the millennium, Evangelical and Pentecostal churches and churchgoers have multiplied, some led by Talamancan pastors, but all with strong links to foreign missionaries and international Christian networks (cf. Rojas 2009). Trade and the monetary economy grow rapidly, while subsistence farming dwindles. Tourism is emerging as an alternative livelihood, generating new incitement and demand for performances of indigenous culture, including indigenous religion (cf. Tafjord 2016a). Several new public health care centres and schools have been built in recent years, and various universities now offer courses and study programmes in or nearby Talamanca. Less than two decades ago, it took a whole day to travel from Barrio Escalante to the nearest public phone in Suretka and back, while today, almost everyone has a mobile phone, many with access to the Internet.

Bribris have become ever more entangled in networks and exchanges generated by colonialism, the state, capitalism, and globalisation, not least through resistance against such structures and much of what they bring about. Yet Bribris have also embraced much of the connectedness, the new technologies, and many of the opportunities that have come along with this. They have responded to the intrusion of state institutions by seizing maximum control of their functions in their territory and Bribrifying them. For example, Bribri leaders have demanded that Bribri language and cultura indígena (Sp. 'indigenous culture') be compulsory subjects in local schools, and they have secured the privilege to appoint the teachers in these subjects (cf. Borge 2012). In recent years, such achievements have involved collaboration with academics, rights activists, and representatives of other indigenous peoples both nationally and internationally.

Based on my observations over many years, I think it is safe to say that a reappraisal and revitalisation of indigenous traditions is ongoing in Talamanca, shaped in part by the new system of education; an increasing commodification of Bribri culture; new approaches to health care; and widespread access to new technologies and media, especially the Internet - all sites where Talamancan practices and situations are translated and compared to practices and situations of indigenous peoples elsewhere in the world. Nowadays many young Bribris speak about their traditions with palpable pride. They talk defiantly about protecting their culture and territory, like their ancestors have done before them. But they do so in a different register than most elders. The geographical and intercultural range of the youngsters' perspectives and references is generally broader. Their talk frequently taps into wider discourses on indigenous peoples, driven by indigenous people and allies, nationally and internationally. It thrives on congratulatory comparisons of how ecological, natural, brave, resistant, knowledgeable, and wise all indigenous peoples are, and on uneasy comparisons of the oppression and the threats that their communities and practices continue to face. 
In other words, the youth engages indigeneity in a wider, more-than-local, and more-than-Bribri sense. Their activism is welcomed by many elders, who say this gives hope for the future, but who also keep underscoring the particularity of Bribri lifeways (cf. Tafjord 2016a).

Some of these elders are school teachers of cultura indigena. In February 2015, in Suretka, the main village in Talamanca Bribri, the anthropologist Carlos Borge and I co-organised a consultation with around 30 such teachers, to discuss the relations between indigenous traditions and exogenous religions. ${ }^{13}$ In addition to the Bahá'ís who are found mainly in and around Barrio Escalante, there are Catholics who are spread all across the territory, who might be the majority, but who do not participate much in public rituals, and the equally widespread evangélicos (Sp.) or Protestants of diverse stripes, including Pentecostals, among whom one finds the most eager church builders and churchgoers. There are also Seventh Day Adventists and a few Jehovah's Witnesses in Talamanca today. Tensions exist between these different religious communities, and between those who participate in or sympathise with any of them and those who do not. Religions and their roles in society are rarely discussed across families and congregations. It is a topic that is avoided, because it is a source of division. Some of the teachers voiced concerns about parents who wanted to keep their children away from the classes of cultura indigena based on the idea that parts of what was taught - like histories about Sibö, or explanations of the practices of the awapa (Br. usually translated by Bribris as médicos indígenas, or 'indigenous medical doctors') - were devilish things. These parents understood their religion and certain indigenous traditions as conflicting. They echoed a dogmatic opposition promulgated by foreign missionaries. This comparison between religion and indigenous traditions was rejected as nonsensical by a series of speakers at our meeting. But subtle differences were noticeable also among the teachers, as the group comprised adherents of various religions. Some mostly kept quiet. Yet, when we were closing with a round of final words from everyone, the refrain was appreciation for the chance to come together to talk about this difficult and important but often evaded issue, and to learn about the experiences and positions of colleagues.

When in Talamanca, I have always been based either with Elías Escalante and his family, in Barrio Escalante and Sibudi, or down by the coast, usually in Puerto Viejo, from where I have made successive excursions to different parts of the indigenous territories. Elías and his family have been my teachers, collaborators, and friends ever since my first visit. They have generously shared their home and daily life with me and showed me how things are done in their community, including how to go about studying issues that affect and belong to them and their neighbours. ${ }^{14}$

In 2001, for almost four months, I went several nights a week to visit Elías' parents, Florinda Escalante and Rosendo Jackson. The latter, then in his 80s, was one of the most learned elders in and around Barrio Escalante. He took me 
on as a pupil. He had trained several anthropologists before me. ${ }^{15}$ His agenda was that I would record, learn, and later share his teachings of la historia y la ciencia indígena (Sp.), by which he meant Bribri history and science as this is institutionalised by persons like himself, who in their youth have undergone many years of training to become authorised specialists in these matters. His pedagogy built on how his own teachers had trained him, although he had clearly adapted it for students like me, who could never become a professional in any Bribri discipline, and who was there only long enough to get an introduction to some of the basics. The drill was for him to recite or sing first in what he said is the original language, that is, the language of things in their true form, and the language that Sibö taught to the first Bribri specialists whom he trained in the beginning of this world. Then Rosendo recounted quickly in ordinary Bribri what he had just sung. Next, he recounted it again in Spanish, now addressing me much more directly. Finally, he switched to an analytical mode, which is to say he deployed a second set of or second-order - categories, often words and phrases from the vocabulary of anthropology, to shed more light on and explain for me the implications of what he had just narrated. Altogether there were four steps. Four rounds of translation. Now and then, when Rosendo hesitated, or when she thought something needed a bit more explication (or a better translation), Florinda's discreet voice would emanate from the kitchen, aiding him along. He started with the histories of the worlds before this world. He insisted I had to learn about them before he could move on to teach me about the history and order of the world we now live in. ${ }^{16}$ Processes of ordering are at the heart of the histories. They are all about trial and failure, or systematic explorations of possibilities until finding well-functioning solutions, which then become prescribed as the 'law of Sibö'.

Whereas Rosendo systematically lectured me, Elías has been my supervisor, guide, and co-researcher, often travelling with me to visit and interview people not only in Talamanca but also in other parts of Costa Rica and Panama. ${ }^{17} \mathrm{He}$ has showed me how to approach people and delicate issues in contexts that he knows intimately. ${ }^{18}$ Our conversations have always involved sharing analyses of unfolding events. Thus Elías, too, translates for me, and with me. Moreover, he helps in translating me and what I do to his community. ${ }^{19}$ Over the years, through our collaboration and friendship, more people have become connected and committed to each other. My family have come along to Talamanca on several occasions, and lately I have been allowed to bring entrusted colleagues. Elías has been central every time someone from Talamanca has travelled to Tromsø, even if he himself has not yet been able to come. All these dimensions and outcomes of our relationship have brought about new learning, new perspectives, and new translations.

\section{Encounters with indigeneities and indigenous religions in Tromsø}

A job in the Department of Religious Studies at what is now called UiT The Arctic University of Norway made me move to Tromsø in January 2007. The 
first Talamancan friend who came to see me there was Heidi. ${ }^{20}$ She was in Oslo visiting a cousin, so I invited her up north for a couple of days. I took her to the university museum and showed her the exhibitions of Sámi culture and history, and in the evening I made a point of watching the Sámi news on TV. As she did not seem particularly interested in either activity, it began to dawn on me that I was showcasing a local indigeneity, as if saying "Look, there is an indigenous people here, too! This is especially interesting for you!" When we addressed this issue directly, it became evident that she saw things differently. To her, there were no skowak, indios, or indígenas in Tromsø, except maybe if somebody had migrated here from somewhere in America. Back then, her notion of who indigenous referred to did not go beyond a continental scale (cf. Tafjord 2016b), it did not include people original to other continents, at least not until I unwittingly began to talk her into expanding it.

'Indigenous Religions' was the name of the first undergraduate course I initiated in Tromsø. I began my lectures by reflecting on lessons I had learnt from Bribris. I told the class that Bribris are proud of never having been conquered, that they rarely compare themselves to peoples outside America, and that they often insist on never having had an indigenous religion, or some of them say that the Bahá'í Faith is their indigenous religion. I also proposed that instead of presuming that Talamanca is a holistic society pervaded by an indigenous religion, it is more pertinent to see it as a society which has been differentiated in ways which are unfamiliar and therefore hard to recognise for outsiders. I told the students how the idea of religion and a corresponding social domain have in fact been introduced in Talamanca by missionaries and state agents, including academics, and how such outsiders are the ones who have imagined an indigenous religion infiltrated through all sectors of Talamancan society. Moreover, I questioned the idea that Bribris live closer to nature than many rural Norwegians and whether Bribris have a more religious relationship to nature. My aim was to present some of the Talamancan particularity and complexity to the students, and, in doing so, challenge stereotypical and exotifying ideas about indigenous peoples and indigenous religions.

I had not spoken long before a student declared that much of what I said was wrong. Although he had never been to Talamanca and never met a Bribri person, he claimed to know how Bribris understood things better than I did because he, unlike me, was Sámi and thereby indigenous like them. Another student who also self-identified as indigenous, but from a different part of the world, agreed, and so did the non-indigenous postgraduate student who was assigned as my teaching assistant. They alleged I was undermining the common cause of indigenous peoples by questioning their defining characteristics.

In this classroom encounter, my attempt to deconstruct what I thought were theoretical presumptions hindering more nuanced understandings of indigenous people and their religions fell short. My reflections on what I had learnt from Bribris did not convince these students, and they became even more provoked 
when I tried to explain how the presumptions that I criticised have their origins in colonialist theories about primitive people and primitive religions (cf. Geertz 2004; Cox 2007; Chidester 2014). In their view, I attacked historical and social facts, not theoretical presumptions. These students identified themselves and other indigenous people with the qualities that I had questioned. They saw them as resources personally, communally, and politically, while mourning how colonialism in the recent past had deprived their ancestors of these cultural riches. If anything represented a continuation of a colonial approach now, to these students, it was my questioning of what they experienced as commonalities of indigenous people.

To me, this was a perplexing experience, which, in hindsight, has proven one of the most sobering lessons in my academic life. In Talamanca, I had been learning about indigeneity and religion from Bribris, as a humble student, never contradicting the perspectives of my hosts and teachers. In Tromsø, I was talking about indigeneity and religion from a privileged position, as the teacher of a diverse group of students, inadvertently disputing what some of them understood as essential features not only of their own local identity and family history but also of the global family of indigenous peoples that they identified or sympathised with. In order to translate insights from Talamanca contextually, respectfully, and convincingly in my teaching, I had to learn more about indigeneity and religion in Tromsø, too.

Located in the Norwegian part of Sápmi, or the Sámi territory, the University of Tromsø or UiT has been a key institution for Sámi revitalisation and indigenous peoples' politicking. The concept urfolk (No.) is central here. It is the official Norwegian translation of 'indigenous peoples' and rose to prominence from the late 1970s onwards, when Sámi political movements grew stronger through struggles against the Norwegian state (cf. Kraft, Chapter 2 about the Altaconflict), after decades of suppressive assimilation policies which had resulted in widespread Sámi language loss and renouncing or silencing of Sámi identities (Minde 2003). The new identification as an urfolk or an indigenous people was spurred on especially by Sámi participation in an emerging international indigenous peoples' movement (Minde 1996, 2008).

In recent years, local Sámi movements and international indigenous peoples' movements have only continued to increase in cultural and political force and interconnectedness (cf. Kraft, Chapter 2; Falch \& Selle 2018; Grini 2016). In Tromsø and Northern Norway, the conceptualisation of the Sámi alongside many other people around the world as urfolk has become the hegemonic discourse, to such a degree that here it is common to translate the English adjective 'indigenous' into urfolk more or less unconditionally: indigenous issues becomes urfolkssaker; indigenous languages becomes urfolksspråk; indigenous art becomes urfolkskunst; and indigenous religions becomes urfolksreligioner. In doing this, activists and academics in Tromsø often forget that the word 'indigenous' may 
be used in various other ways. For example, it can be used in a contextually contingent sense and merely mean that something or someone pertains to a particular place and a particular community, in opposition to anything or anyone exogenous or foreign, regardless of whether that community is recognised politically or legally as an indigenous people by international institutions or members of an international indigenous peoples' movement. ${ }^{21}$

In Northern Sámi, the main Sámi language spoken in the northernmost parts of Norway, Finland, and Sweden, álgoálbmot and eamiálbmot are the standardised translations of urfolk and indigenous peoples. However, in and around Tromsø, like in most other coastal areas, Norwegian is the dominant language also for most Sámis. The linguistic variation is considerable. In addition to the national languages of the nation states that Sápmi is part of, Finnish (Finland), Norwegian (Norway), Russian (Russia), and Swedish (Sweden), there are at least nine official Sámi languages, which are not mutually comprehensible. Livelihood, material culture, and religion are other fields of significant internal difference, not only today but also historically (cf. Rydving 1995, 2010). Heterogeneity, internal strife, and tensions characterise all Sámi communities, and Sámi society at large - like any other vital society. Yet, over the past century, Sámi unity has been emphasised by Sámi leaders whenever they have been dealing with the Norwegian state. They have also persistently underscored their unity across the borders of Norway, Sweden, Finland, and Russia. On top of this, pan-Sámi peoplehood has been cultivated in relations with other indigenous peoples and international institutions like the United Nations. In other words, it is especially when engaging in state and foreign affairs that Sámi leaders have been careful to present themselves as representing one people, and, increasingly during the last half century, a people of a special kind, very particular in its own right but also a local variant of a global generic: an indigenous people, urfolk, álgoálbmot, or eamiálbmot.

Today, new generations of Sámis assert their identities through these naturalised concepts. In Sápmi, especially on the Norwegian side, several institutions have been built to provide material, intellectual, and political support and authority to the revitalisation of Sámi languages, identities, and traditions. The most notable are the Sámi Parliament, the Sámi Museum, and the public broadcaster NRK Sápmi with their headquarters in Kárášjohka, and the Sámi University of Applied Sciences in Guovdageaidnu, but there are also numerous local museums and cultural institutions in other communities across Sápmi. Art and artists have played prominent parts in all these institutions and, more generally, been the avant-garde in the contemporary renaissance of Sámi identity and indigeneity. Music, fine art, poetry, handicraft, literature, theatre, film, fashion, and festivals are at once prestigious and popular media for diverse expressions of Sáminess and indigenousness. Public schools and health care services now have special programmes for Sámi pupils and patients. Tourism, too, has become a serious venue for performances of Sámi and indigenous culture for community members as well as visitors. 
Since Norway ratified the International Labour Organisation's Indigenous and Tribal Peoples Convention (ILO169) in 1990, being urfolk has also become a legal issue. ${ }^{22}$ Sámi actors have had important roles in what is now the United Nations Permanent Forum on Indigenous Issues and in the making of the United Nations Declaration on the Rights of Indigenous Peoples, formal global platforms for the forging of political alliances and for claiming of difference. ${ }^{23}$ Both the Norwegian state and Sámi leaders have been eager to work with and through the United Nations, and to collaborate in the continued development of international networks and frameworks.

At UiT, the largest public university in Northern Norway, various research projects and study programmes focus on issues concerning Sámis in particular and urfolk in general. It is part of the official strategy of UiT to do research, teaching, and outreach that shed light on the situations of indigenous peoples locally and globally. The Centre for Sami Studies coordinates many of the efforts in this regard, among them a master's programme in indigenous studies, taught in English by faculty from various departments. ${ }^{24}$ This programme recruits students from different parts of the world, and applicants who are classified as urfolk or indigenous get priority. The compulsory courses introduce the students to general characteristics and rights of indigenous peoples, and it is largely through these lenses that they then study particular cases. For their dissertation, the indigenous students are advised to do research in their home communities. The scholarship that has allowed students from places like Bangladesh, Brazil, and Ghana to come and take the programme is turned into a loan if they do not return home after they graduate. The idea is that they shall become resources in their communities. A recent celebrated case is a former alumni's founding of a centre for indigenous studies at Dilla University in Ethiopia. ${ }^{25}$ Other UiT initiatives that have had an impact on understandings of indigeneity elsewhere include programmes for capacity building among Mayan indigenas in Guatemala and among the San people in Botswana and Namibia. Through these programmes, UiT produces and exports a particular perspective on indigenous peoples.

Nonetheless, UiT hosts a range of perspectives, and lively debates about the interface of indigenous peoples' politicking and academia. Like at many other universities, there are tensions between those who want to decolonise academia by replacing what they see as Western approaches with indigenous methodologies; those who are sympathetic to changes that can bring about a greater diversity of perspectives (myself included) but reluctant to go along with the inverted dichotomies (like Western versus indigenous) that some activist scholars now endorse; and those who are sceptical or downright opposed to this challenging of established academic procedures and privileges.

The diversity of perspectives notwithstanding, most scholars in Tromsø, like most scholars elsewhere, teach students that indigenous peoples have an indigenous religion or an indigenous spirituality. They simply take this for granted. They do it although they know that most Sámis, like most Scandinavians, are Lutheran Christians, some of them very liberal and some of them very conservative. ${ }^{26}$ An idea about the presence of an indigenous religion or spirituality 
that pervades both their Christianity and their daily lives is widespread in both scholarly and Sámi communities. From the 17th century onwards, Lutheran missionaries and other state agents attacked what they saw as Sámi superstition and idolatry. Later, scholars have reconceived many of the persecuted Sámi practices and objects as elements of an indigenous religion, and studied how they were abandoned or changed over the centuries in encounters with Christianity (e.g. Rydving 1995, 2010).

Recent years have witnessed an upsurge in public articulations and performances of Sámi indigenous religion in the form of shamanism and animism, partly influenced by New Age and paganisms (cf. Fonneland 2017; Kraft, Fonneland, and Lewis 2015; Kraft 2015), and in the form of Christian Indigenous theology, mostly but not only under the auspices of the Church of Norway (for example the Sámi liturgies and theologies of Bierna Bientie and Tore Johnsen). ${ }^{27}$ Those who spearhead these movements draw on their personal experiences, and often their family history. Missionary accounts and historical scholarship about the Sámi are common sources for them. In addition, they share an interest in anthropology and ecology, especially in ideas about nature religion and natural religion. Many have been students in religious studies or theology programmes. Inter-indigenous encounters, comparisons, and exchanges, especially with Native Americans, also inspire them (cf. Kraft, Chapter 2). With their ideas and practices, the shamans and the Indigenous theologians have created new alliances in and beyond Sámi communities, but also new tensions as they provoke both conservative Christians concerned with doctrine and scholars concerned with authenticity.

Many of these tensions, and most of the public discourses on religion and indigeneity in the Norwegian part of Sápmi, are either absorbed or disregarded and thereby largely neutralised by the Church of Norway. This dominant religious actor has a near naturalised (and therefore not always noticed) position in a national society whose public domain is often imagined as one of the most secular in the world. ${ }^{28}$ The Church of Norway includes a broad spectre of Sámi voices. Despite its history as a major state enforcer, responsible for rigorous missionising in Sápmi, it has managed to rebrand itself as a defender of Sámi interests in relation to the state and, partly through the World Council of Churches, as a promoter of the rights of indigenous peoples internationally, even as it continues to engage in missionising all across the world. Today it occupies the lion's share of the religious sphere in Sápmi. Beyond its domain, religion or religiosity has seldom been articulated in broad public discussions of Sámi issues, or in the functioning of other Sámi institutions. However, this might be changing now with the growth of Sámi shamanism (Fonneland 2017) and new forms of environmental activism (Kraft, Chapter 2).

The practices and politics of indigeneity hinged on religion in Sápmi are varied and complex. This is the case in Talamanca, too, but in other ways. Not only are the ideas and practices that get articulated as religion very different in these 
two contexts. The social domaining of religion, and its relating to indigeneities, are also done differently.

Yet, there are also some striking similarities. In neither place is religion normally foregrounded in public performances of indigeneity which aim at uniting the entire indigenous community. Whenever a religious actor takes the liberty to speak as if on behalf of the indigenous community at large, it is disliked but generally ignored by those who do not adhere to her or his congregation. In practice, religion does not serve to keep any of these indigenous communities together, nor to mark their boundaries, because they are both too heterogeneous in this respect. The cross-fertilisation of indigeneity and religion in Sápmi and Talamanca alike seems to have taken place mainly in small-scale and mediumscale domains, typically within the family and the religious congregations.

However, in the broadest and most public community settings in both Sápmi and Talamanca, there is sometimes talk of andelighet (No.) and espiritualidad (Sp.), or spirituality, as a hallmark of indigeneity. This may function, internally in the communities and in encounters with outsiders, as something akin to what Siv Ellen Kraft (2017) has construed as a 'diplomatic language' of indigeneity, in the sense that it enables everyone to come together without necessarily agreeing about the specific content of that which they gather around. As long as they are open to different interpretations, religionists need not see it as an expression of a different religion, whereas secularists need not see it as religion or religionish at all.

Exchanges in inter-indigenous encounters, whether face to face, as long range interaction through social media, or via engagement in international indigenous peoples' politics, might represent expanding spaces and inducements for articulations of indigenous practices as spirituality or religion. So might an increasing exposure to academic theories about indigenous peoples and their indigenous religions, partly through growing participation in public educational systems or through contact with researchers who conceptualise indigenous religions. ${ }^{29}$ Sometimes those who do religionise or spiritualise Sámi or Bribri practices might do it strategically since, according to several international legal conventions, religion releases special rights for that and those who are recognised as such. But these translations may also put the relevant practices in a vulnerable position because they invite attacks from missionaries and others who wish to replace indigenous religions, either with what they think of as better religions, or with what they imagine as more rational practices. ${ }^{30}$

\section{Talamancans in Tromsø}

In May 2018, more than ten years after her first visit, Heidi came for a second two-day visit to Tromsø, this time formally invited by our research group to give a talk about indigenous rights in Costa Rica in theory and practice. She had become the first female lawyer from Talamanca just a few months earlier, and now she had won a scholarship and was spending two months in Bilbao, 
Spain, taking a course on indigenous peoples' rights at the University of Deusto. This time Heidi came to Tromsø with a different view, formed by her studies and the networks she had become involved in while studying. ${ }^{31}$ She has become an ardent defender of indigenous peoples' rights - of the rights of Bribris and other Costa Rican indigenas in particular, but also of the rights of indigenous peoples globally. Since her first visit, her idea of who indigenous peoples are had expanded, to resonate with urfolk in Tromsø.

In her talk, Heidi explained that although the Costa Rican state has ratified and routinely expresses support of international legislation on the rights of indigenous peoples, in practice, its institutions do not live up to their obligation to respect the indigenous cultures. She gave examples of the consequences of this neglect - in education, child protection, the judiciary, housing programmes, and land tenure. She stressed that indigenous history, traditions, and spirituality are regularly rejected by state officials and leaders of missionising religions. ${ }^{32}$ To characterise the attacks on traditional Bribri practices, she used the word satanización (Sp.). She related how Bribris have learnt from their elders that Sibö dwells in a world above our world, and Sula in a world beneath ours, and how this knowledge regulates Bribri society in fundamental ways (cf. Bozzoli 1979). Those who denounce these ideas target in particular the awapa (Br. pl.), whom Heidi translated as médicos indígenas ('indigenous physicians'), and especially the ritual acts and songs which complement their prescription, production, and application of pharmaceuticals. According to Heidi, these dismissals of indigenous knowledge and spirituality represent violations of the rights of an indigenous people to practice and preserve their culture.

With reference to legal frameworks sanctioned by the United Nations, and idioms common in the discourses of this organisation, like the notion that spirituality is a core element of indigenous cultures (cf. Kraft 2017), Heidi translated concrete practices and experiences from her community. She made them comparable to - and thus recognisable and relevant for - experiences that colleagues and students in Tromsø had from the communities they belong to or work with. In this way she educated the audience about the situation in Talamanca and Costa Rica, a country which continues to use its international image as democratic, peaceful, ecological, and socially conscious to dodge negative publicity about its negligence of indigenous communities. ${ }^{33}$ From Bilbao and Tromsø, Heidi continued to Geneva, where she spent a month contributing to and learning more about the workings of the United Nations. Her internship there culminated in the opportunity to give a formal critical response in public to the Costa Rican government's presentation of its annual report to the international community about the situation for 'its' indigenous peoples.

Three years earlier, in October 2015, I had the honour of bringing the distinguished Bribri leaders Alejandro Swaby and Justo Avelino Torres Layan to Sápmi, along with the Costa Rican anthropologists Carlos Borge and Sandra Esquivel, 
for a seminar on the situation of indigenous peoples in Costa Rica and a conversation about indigenous methodologies at UiT. ${ }^{34}$ After these events in Tromsø, we drove to Guovdageaidnu and Kárášjohka, two Sámi majority communities on the tundra which host key institutions like the Sámi University of Applied Sciences, the Sámi Parliament in Norway (Figure 1.4), the headquarters of the Sámi division of NRK (the public Norwegian Broadcasting Corporation), and several Sámi museums. ${ }^{35}$ The encounters that took place in these communities and institutions encouraged comparisons and required translations. Indigeneity was the main premise for the comparisons, a tertium comparationis, largely predetermined through the agenda and the appointments that I had made in advance. Spanish and English served as linguistic middle grounds, between Bribri on one side and Sámi and Norwegian on the other side, with me often given the role as translator although aided by everyone involved, turning the translating into a collaborative effort. I had previously visited these places and institutions (except NRK) with Monica Grini, a historian of Sámi art and nation building, when she was doing research there (cf. Grini 2016). She accompanied us on this tour as well, sharing her knowledge and introducing us to people.

Alejandro Swaby, now in his 80 s, has been a prominent political leader and intellectual all his adult life: in the Talamanca Bribri community where he grew up as a member of the prestigious clan of his mother; in the coastal community of African descendants which he belongs to via his father's family; and in national and international movements and organisations of pueblos indígenas or indigenous peoples. He comes from, and now heads, a family of leaders. ${ }^{36}$ From childhood his education was both internal, with some of the most learned elders in the Bribri community, and external, as he was sent to Limón (the main town on the Caribbean coast of Costa Rica) to attend school. He speaks perfect Bribri,

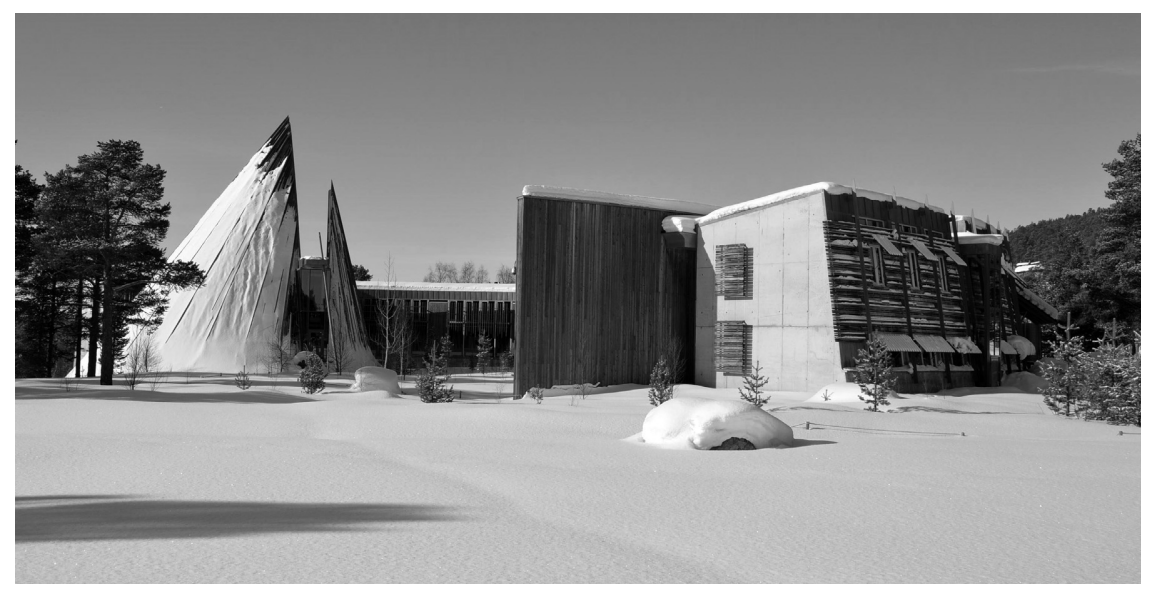

FIGURE 1.4 The Sámi Parliament in Kárášjohka.

Source: Illustratedjc, CC BY-SA 3.0. 
Spanish, and English, and he is very well versed in Bribri, African, and European cultural and intellectual traditions. He has served as the president and advisor of the Asociación de Desarrollo Integral del Territorio Indígena Talamanca Bribri (ADITIBRI), which is the official internal government of his indigenous territory; as the mayor of the larger Talamanca county, which also comprises the coastal communities of African descendants and a mix of migrants and settlers from elsewhere; as the head of the Mesa Nacional Indígena de Costa Rica, which he co-founded as a political working group for leaders from different communities of indigenas in the country; and as the president of the Consejo Indígena de Centroamérica (CICA), a regional forum for collaboration between organisations of indigenas, and a node in the networks of a larger international movement of indigenous peoples. He has travelled widely and met leaders of indigenous communities from different parts of the world. Among Talamancans, his international experience is unique. Upon arrival in Tromsø, he told us how he had befriended Sámi leaders, in particular the South Sámi Leif Dunfjeld, at international meetings in the 1980 s.

Alejandro's skills as an advocate and diplomat of indigeneity were evident to everyone who met him here in 2015. In his public talks, and in the conversations we had with representatives of Sámi institutions, he addressed a series of emblematic topics in international discourses about indigenous peoples: care for and harmony with nature; traditional knowledge and spirituality; resistance against colonialism, extractivism, and capitalism; and stubborn survival thanks to the ancestors' astuteness in the face of extreme violence and exploitation. The way he voiced these topics, including asking how they play out in Sápmi, put emphasis on local particularities. But, in order to make the local particularities mutually comprehensible, he and the Sámi conversation partners articulated or translated them with a vocabulary or into a language that has been developed and become customary in international relations between indigenous peoples. They built bridges for comparisons and means for identification with each other, using a common repertoire of idioms and tropes. Alejandro and the internationally experienced Sámi leaders did this with ease and elegance. The occasions for such diplomacy were the formal highlights of the tour for Alejandro. ${ }^{37}$

Alejandro and Justo Avelino Torres Layan refer to each other as akëkëpa (Br. 'respected elder'), a gesture of reciprocal reverence. Justo Avelino is in his 30s and, despite his young age, one of the most respected awapa among the Bribri. He comes from a prestigious ditsö or clan, and a family of eminent community leaders. He studied with one of the most renowned awapa of the former generation. Justo is also óköm (Br.), which means he is trained and called on to perform Bribri funeral rituals. For these offices, he has several young apprentices. He also works as a teacher of cultura indígena in primary schools. Thus he is continuously passing on knowledge to youngsters who seek him out in the hope of one day becoming specialists themselves; to all the children who have to take classes of cultura indígena at school; and to anyone who comes to him for consultation, medical treatment, or funeral services. In the Bribri community, he is a guardian, 
practitioner, disseminator, and enforcer of traditional knowledge and practices and their value. In the growing national movement of young indigenous activists, people look to him for guidance and inspiration. In Costa Rica he is very well connected, through both the most traditional and the newest and most mediatised social networks. Like most Bribris of his generation, while he is concerned with practising and revitalising traditional Talamancan ways of relating, he also uses the latest technology - his laptop and smart phone - to participate in broader networks where relating of indigenous issues, in wider senses, takes place.

This was Justo's first international trip. In the presentations he gave, and in conversations with the people we met in Sápmi, he focused even more than Alejandro on Talamancan particularities. His primary concern was to share the basic ideas of what he called the Bribri cosmovisión (Sp. 'worldview'). He used the blackboard to draw a cone shaped and vertically multi-layered model of the world for us, indicating the locations of and relations between the living spaces or homes or houses of Sibö, Sula, and us humans. He spoke slowly using colloquial words in Spanish, including concepts that frequently circulate in social media and academia to characterise different aspects of indigenous lives and worlds, like la espiritualidad indigena ( $\mathrm{Sp}$. 'the indigenous spirituality') and la cosmovisión indigena (Sp. 'the indigenous worldview'), but he also introduced key concepts in Bribri, like Sulakáska (the house of Sula, in a world beneath our world) and siwá (history, knowledge, breath), and in between this he sang short stanzas in the ritual language, which is said to contain the original knowledge in its original form (cf. Bozzoli 1979; Cervantes 2003). I remember thinking that this must be how he does it when he introduces the school children to these ideas. When I asked him about it afterwards he laughed in a friendly manner and said "Yes!" He added that, since he has much more time with the children, he tells them more of the many historias (Sp. 'histories') which are among the main vehicles of this conocimiento (Sp. 'knowledge') and cosmovisión. The time restraint made it necessary to be more abstract and general with us. The children get a more grounded and thorough introduction. His vast pedagogical experience - with his own masters, with his own apprentices, with the school children, with his patients, with his community, with members of other communities of indigenas in Costa Rica, with missionaries and religious leaders who have criticised him and the awapa in general, and with researchers who had come to talk to and learn from him - had prepared him to translate his basic ideas to us in this straightforward yet particular way.

Justo was very interested in Sámi histories and practices. He noted how they were so different and yet in some aspects similar to Bribri histories and practices. He listened attentively to everything that was said about Sámi traditions during the trip, especially when somebody Sámi was speaking. Afterwards, each time I have met him in Talamanca, I have been stunned by the details he recounts. The encounter that seems to have made the strongest impression on him was with Mai Britt Utsi, then dean of the Sámi University of Applied Sciences. The 
generous way in which she received us, first at the university together with its former rector Jan Henry Keskitalo, and then in her private home, together with her husband Nils Thomas Utsi and their family, was, to Justo, a true echo of Bribri values and the epitome of indigenous ideals more generally. When he speaks about his memories from Sápmi, he highlights Mai Britt's sharing of histories, knowledge, food, time, and friendship, and her dignified embodiment of her culture. The climax of the encounter for Justo was when she performed a yoik (a traditional Sámi vocal art) for us, whereupon he, encouraged by all of us, reciprocated with some carefully selected melodious strophes from the Bribri repertoire of histories in their original language. In this exchange, my translating became redundant. It was neither the words nor their content that were the main things exchanged or translated and compared. It was the acts and arts, including their aesthetics and honours. This generated the most profound recognition.

Justo remembers Mai Britt as la hermana (Sp. 'the sister'). Kinship terms sister, brother, cousin - were used during our tour by both the Bribris and Sámis to refer to members of the other group. Such extensions of kinship are quite common in inter-indigenous encounters. It is a way of reaching out to each other, saying that we are of the same kind, we share something essential, we are comparable, we are kin. Greg Johnson and Siv Ellen Kraft (2018; cf. Kraft, Chapter 2, and Johnson, Chapter 5) have theorised that a notion of 'distant selves' enables enactments and sentiments of a global indigenous community. I would like to add that extensions of kinship often seem key to how experiences of shared identity through indigeneity come about in cross-cultural encounters. The translating of the other into family affords an upscaling and enlargement of one's intimate community. It may be one of the basic gestures that make global indigeneity imaginable and tangible. Of course, it results in relative relatives. Yet, the kinship designations function as more than metaphors. They create or confirm close bonds. They forge or maintain commitment to alliances. Taking serious such extensions of kinship, which typically occur as a result of travel or cross-territorial connecting, and considering them in light of the theory of James L. Cox $(2007,2016)$ who suggests that the defining ingredients of indigenous religions are kinship and territory, offers an interesting perspective: while territory is difficult and often impossible to enlarge, easily overpopulated and drained, and frequently threatened by colonisers and usurpers, kinship is always a matter of degrees and flexible. The family never gets full. Insofar as practices of territoriality and kinship define indigeneity and indigenous religions, the latter is definitely the most scalable.

As part of their profession, the Costa Rican anthropologists did also master an international language of comparative culture and indigeneity. Carlos Borge has done anthropological work in Talamanca since the 1980s and is probably the non-indigenous scholar who knows most about this region's recent history and social life. He and Sandra Esquivel have worked closely together for over 20 years, running a small consultancy firm, often doing impact evaluations in territories of indígenas in Costa Rica and elsewhere in Central America. During 
their visit to Sápmi they were, as always, enthusiastic. In line with the anthropological ethos and habit, they kept asking kind and curious questions, and they liberally shared their instantaneous comparative analyses of Bribri and Sámi practices, as well as comparisons of Bribri or Sámi practices with the practices of other indigenous communities that they knew. In short, they offered us their service as cultural translators and commentators. They did what anthropologists do - not unlike what everyone in the INREL group would do in different but comparable situations later.

We who toured Sápmi together spoke Spanish among ourselves, except for Alejandro and Sandra who spoke English with Monica. Even if Alejandro and Sandra spoke English very well, in our encounters with Sámi persons, our conversations predominantly took place in, and between, Spanish and Norwegian, since Justo and Carlos do not speak English, and most of the Sámi persons said they were more comfortable speaking Norwegian. As our exchanges progressed, it became increasingly clear to me that I was constantly translating translations: pedagogical, political, and analytical expositions of ideas that had sources elsewhere but became formed here and now, in these encounters. If much of what was said was already second-order talk, then my translations of it were third-order.

During our long drives, I told the visitors about the history of religions in Sápmi, and we talked about the history of religions in Talamanca. We compared Sámi and Bribri practices and how they have been targeted by Christian missionaries and by state agents more generally. All the same, and even though I tried to bring it to the table a couple of times when I thought it opportune, religion did not become a topic in the conversations between Alejandro and Justo and the Sámi persons who interacted with us. In these at once diplomatic, pedagogic, and friendly encounters, religion was not employed as a method for relating and comparing. It was not addressed, neither as a historical exogenous force nor as an internal aspect of the respective indigenous societies. On the contrary, there seemed to be a silent agreement between the two parties to avoid this topic, and to speak - and thereby relate and compare - through other concepts, themes, or registers. Put differently, religion was not articulated or performed as part of the indigeneities that met and shared, despite my attempts to inject it. Although the recurring references to 'spirituality' can easily be read as articulations of indigenous religions, this requires an additional act of translation, one that was not played out in the exchanges themselves.

When we, at the end of the trip, sat down together and reflected on what we had learnt, the Costa Ricans all emphasised how impressed they were by the particularity and strength of Sámi claims of indigeneity and by the strong presence of a political discourse on the rights of indigenous peoples worldwide. Everyone was intrigued by the wealth, resources, and modernity of the Sámi institutions. The two Talamancans admitted, discreetly, that they had the impression that these institutions are so incorporated in the Norwegian state that they have little proper autonomy. For example, they were surprised to find out that the Sámi Parliament cannot issue laws. The anthropologists described how they had seen a pervading modernity and even postmodernity in the Sámi lifeways 
and institutions. As examples they remarked that Sámi and Norwegian private houses seemed similar, and that the architecture of the new Sámi institutional buildings was definitely untraditional. They interpreted this as symptoms of loss of original culture.

All four visitors acknowledged how little they had known about Sápmi upon arrival. The things I had told them in preparation for their visit, and in earlier attempts to position myself, had generated only a vague awareness for Justo, Carlos, and Sandra. Alejandro knew a bit more from his previous encounters with Sámi leaders. Now they all emphasised how much they had learnt over the past week. Recurrently, in conversations with each other, Bribris, Sámis, and anthropologists had commented on the striking similarities between the histories and situations of the indigenous communities in Costa Rica and Scandinavia. Now our four guests did this again. However, the Bribris and the Sámis we had met had spoken much more about particularities than about similarities. Now Alejandro and Justo underscored the enormous differences once again - among them the long Sámi history of relatively peaceful co-living with Norwegians, Swedes, and Finns versus the genocide that followed the abrupt arrival of the Spaniards in Central America and the violence that still haunts the indigenas of this region.

\section{INREL in Talamanca}

In January 2018, the INREL research group went to Talamanca. At first, the idea of taking a group there had made me nervous. Who was I to do this? I have always felt partly like an intruder in Talamanca. Politely but clearly, Bribris have let me know that I have no rights there. The longstanding friendships and the certainty that my regular visits have been seen as gestures of loyalty and respect did not keep me from doubting the appropriateness of me bringing along several other researchers. But Elías had calmed me. On several occasions, he had hosted groups of students from the University of Costa Rica, brought by another old friend of his, a professor of geography. In fact, Elías had recently expanded his family's house to be better prepared to receive visiting groups. He was curious about my colleagues and wanted to meet them. This was an opportunity for him and his family as well, so we organised a two-day visit to their place in Sibudi.

It had rained heavily for days and the rivers were swelled as we headed up into the Talamanca valley, first by car from Cahuita to Suretka, then by boat up the River Telire to Sepecue, and finally by bus to Sibudi. With rubber boots, rain coats, and backpacks we followed the flooded trail leading to Yari and Elías' house, set in between cocoa and banana plantations, and surrounded by a bountiful kitchen garden, 200 or 300 metres from the gravel road and the electricity lines. They gave us a hearty welcome, warm drinks, and food, before we hung our hammocks and rested for a while.

In the afternoon, Elías took us first to the house of Lorena and Misael, his brother, to say hello but also to invite us to chat with them as they are among the most engaged members and leaders of the Bahá'i Faith in the local community. 
He introduced us as university professors investigating religions among indígenas all across the world, in India, Hawai'i, Nigeria, Norway, and the USA, and asked Misael and his son to tell us about the Bahá'í Faith and its relations to indigenous traditions. As usual, they spoke Bribri to each other and Spanish to us. Elías translated from Bribri to Spanish for us whenever he found it timely. I had the task of translating into English for my colleagues. I found myself doing both linguistic and cultural translation simultaneously, in real time, and it was hard. People often spoke several long sentences before they gave me a chance to translate, so many details escaped me and got lost even before translation. Of course, as he showed us around, Elías, too, was doing cultural translation for us, and so were Misael and his son who now began to explain, for our benefit, what they saw as the basic relations and similarities between the Bahá'í Faith and their indigenous traditions. It became a very pedagogical situation, but complicated and bent by my translations of their translations.

They told us about the messengers of God, Bahá'u'lláh and Sibö, the latest and the first; he who instigated the Bahá'í Faith and a new global era; and he who came specifically to the first generation of the Bribri. Essentially, their messages were the same, they explained, but Bahá'u'lláh’s message was more advanced than that of Sibö because mankind with time has become more mature and ready to understand more of God's will. Misael went on to emphasise how the Bahá'í Faith teaches that cultures should be appreciated, and that one must take care of that which is valuable in a culture. Therefore, he concluded, the Bahá'í Faith reinforces and renews cultures, both the Bribri culture and other culturas indigenas. The rest of the family expressed their consent.

They were not just comparing but translating basic indigenous traditions (the story about how Sibö taught the first Bribris all they needed to know) into the basics of the Bahá'i Faith (the story about Bahá'u'lláh being the latest in a series of messengers from God). It was interesting to hear Misael do this again. Like much of what Elías told the group during the two days we spent with him, these were thoughts that I had not heard expressed this plainly and pedagogically in many years. It reminded me of how I was received and what I was told during my first two stays there. Of course, all these ideas had been commented on and alluded to frequently in conversations over the years, but, presumably because people knew I already knew about them, they had not reverted to presenting them in this simplified way again until now, when they were not so much speaking to me as to the colleagues that I had brought along.

Afterwards, we continued down the road to look at the Bahá'i centre with its meeting house, kindergarten, communal kitchen, and new office for a small development project that some of the Bahá'is are running, all set in an attractive, fenced garden. ${ }^{38}$ Soon, Ronny Sánchez turned up. For about a decade, he has been a prominent Bahá'í leader not just in Talamanca but also nationally and internationally. I had run into him two weeks earlier, told him about the group that was coming, and asked him to share some of his experiences and visions with us. Since it started to rain again, he invited us into the new office to sit 
around a large table, creating a rather formal setting for our conversation. He, too, explained to us how the Bahá'í Faith is an indigenous religion - the religion of indigenous peoples all across the world - and how it promises that indigenous peoples will enlighten the rest of the world. He also asked for questions from us. Again someone wanted to know whether the teachings of the Bahá'í Faith did somehow come into conflict with Bribri customs. No, said Ronny categorically. Like Misael before him, he claimed that, quite the contrary, the religion reinforces the values of the culture because it teaches people to emphasise the positive parts of their traditions and to abandon negative practices.

While doing my best to translate Ronny's explications and my colleagues' courteous questions, it struck me how I knew that, behind what was said here, things were far more complex on both sides of the table. While Ronny, like everyone at Misael's, was eloquently offering the visitors the basic teachings, more a doctrinal map than an accurate description of the rugged terrain of life, my colleagues were asking polite questions that elegantly masked several of their theoretical and political concerns. The new vantage point that my mediating role in this conversation created made me draw on insights accumulated through my long engagement in both communities - with Bahá'ís in Barrio Escalante and Bribris in Talamanca more broadly, and with the INREL group and academia more generally - to realise that, as both parties were doing their best to approach each other in a friendly and instructive way, they systematically left out intricacies that might have made them come across as complicated or critical. This made me think about how Bribris must have done the same to me on numerous occasions and how I must have done it to them. Anyway, now was not the moment for me to interrupt, neither with critical meta-reflections on past interaction, nor with comments that could have changed the impressions that were being given and taken as we were speaking. Yet, as I was translating, I caught myself inserting additional details, or slightly twisting the words of the other speakers, in intuitive efforts to contextualise and thus try to bring more nuance to the discussion, enhance mutual understanding, and, undeniably, prove my own points. All the same, while indigeneity and religion served as conceptual middle ground or meeting points in our dialogue, nobody delved deep into what we meant by these terms or into how complex the practices and relations that they point to are from both Bribri and academic points of view. We spoke as if these issues were easy and transparent.

The following morning we were supposed to see the pastor of the Pentecostal church in Sibudi, but rain restricted our movement, so we waited and chatted with Elías. Greg Alles interviewed him about whether and how Bribris celebrate the International Day of the World's Indigenous Peoples on 9th August, like he had done with Heidi in San José a few days earlier, taking notes and showing great interest in all the details that Elías could supply. By the time the rain ceased, the pastor was off to his farm to harvest bananas. It was his bi-weekly delivery day. Securing an income trumps conversation with scholars of religion, even for pastors. Instead, Elías took us to his own farm and told us about the basics 
of Bribri livelihood. He explained how the monetary economy has transformed both agricultural and sociocultural practices, and created widespread dependence on tiny and unstable revenues from monocrops, primarily bananas and plantains. The traders pay less for fruit farmed in the traditional ecological way than for the neater looking products grown with agrochemicals. Deforestation, erosion, pollution, less subsistence farming, less communal work, less sharing, more poverty, and more reliance on products, actors, and forces from outside Talamanca are only some of the results. Rapid population growth puts additional pressure on the limited land. All this affects social dynamics and structures, including gender roles, kinship relations, and generational differences, and ultimately ideas and practices of Bribriness, indigeneity, and religion.

After spending the next day in Puerto Viejo, on the coast, discussing ideas for the present book, we went for a second excursion to the Bribri territory, this time to Shuabb with Alejandro Swaby. From Bratsi, two canoes took us up the River Yorkín, the practically unpatrolled border between Costa Rica and Panama.

The place where Alejandro was taking us, the compound of the Asociación Comunitaria de Ecoturismo y Agricultura Orgánica de Talamanca (ACEATA), has been set up for educational, economical, and political purposes (Figure 1.5). A group of women from the local community has founded it as a cooperative, to educate each other, their families, and neighbours, and to receive students and

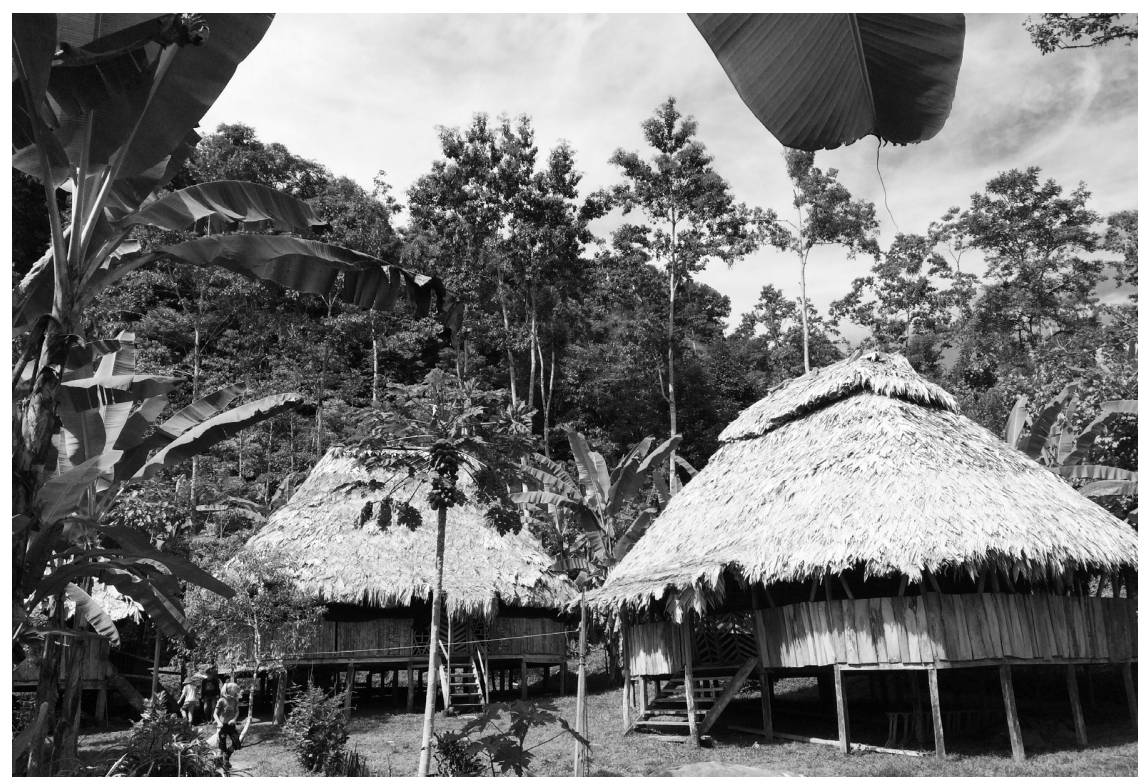

FIGURE 1.5 The compound of the Asociación Comunitaria de Ecoturismo y Agricultura Orgánica de Talamanca (ACEATA) in Shuabb. 
tourists from the outside; to teach and appreciate traditional knowledge and traditional practices; and, at the same time, take control and advantage of research and tourism to help each other gain much needed extra income. The year before, Alejandro had brought me and my family to introduce us to this place, its people, and the beauties and hardships of life there. This is the community that he is originally from, the place of his ditsöwö or clan, the location and the kinship relation that define his indigeneity within the larger Bribri indigeneity. ${ }^{39}$ Now I had asked him if he would accompany our group of researchers, help us learn more about community projects, and coordinate a visit so that we could support the efforts of the women in Shuabb. Upon arrival, they served us refreshing drinks and delicious food in their big kitchen. When we had eaten and rested for a while, Maribel Iglesias, the current president of the cooperative, gave us a presentation of the history and aims of the cooperative and a tour of the compound which includes a large sleeping house, bathrooms, a system for purifying water (installed some years ago by students from the University of Michigan), and an experimental garden of herbs and vegetables. Afterwards, as conversations continued, she and Alejandro told us bits of local history and shared some of their hopes for the future of this place: that more people like us should come and visit them, stay over, learn about their culture, and contribute not only economically but also to the preservation and development of local knowledge and practices in respectful dialogue with scientific knowledge and practices. Before we left, another member came by to show and sell us her traditional artwork.

Back in Bratsi, after a swift ride down the rapids of the Yorkín, Alejandro invited us to make a stop at another women's cooperative, this one organised by single mothers to support each other and their children. Many women have important positions in their families and in the larger Bribri society, as owners of land, as respected leaders, and, in the younger generation, as professionals. However, the increasing influence of socio-economic structures and dynamics from surrounding societies, especially a combination of monetary economy and machismo, has put numerous Bribri women and children in more dependent and vulnerable situations. The resourceful members of the cooperative in Bratsi were making and selling chocolate, cakes, and other local delicacies. They offered us their tasty products and told us about their struggles. Here, in the lower parts of the territory, on its frontier, influences from outside are stronger and changes have happened faster than further up in the valley and the mountains.

The INREL fellows helped turn or return my attention to issues in Talamanca that they noticed with fresh eyes and considerable experience from studies of indigeneities and religions elsewhere. Their remarks on sovereignty particularly prompted me to think more about Bribri postures, practices, and environments that had impressed me deeply when I first arrived there, but that I had begun to take for granted. My colleagues' interest in the multiple natural and man-made boundaries - the rivers, the rough roads, the electricity lines, the national border, the mountains, the forest, the settlement patterns, the different languages, and 
more - as parts of the Talamancan technologies of sovereignty, reminded me of how basic this is for an understanding of the history and the contemporary political situation. ${ }^{40}$ Likewise, their interest in gender roles reminded me of how powerful the matrilineal kinship system is in almost all domains of Bribri society, even if it is constantly challenged in multiple ways, including by patriarchal religions and male dominated politics.

Observing how my colleagues met and were met by persons and places that I have known for years, and having the role of mediator and translator, has made me reflect on my own history of relating and learning in Talamanca. It has made me more aware of the particularity of my relationships, and how they have developed over time, but also of their trivial commonality - both in terms of how foreigners are generally treated in Talamanca and in terms of how researchers generally act in the field. By bringing a collective of scholars, it became clearer to both me and my Bribri collaborators that I represent more than myself that I am an actor in and of a particular international academic community, a world into which Bribris get dragged partly because of me, where some of their ideas and practices are translated into indigeneity and religion, compared to such things elsewhere, and scrutinised for other purposes than their own.

The net of relations and commitments obviously increased with the introduction of my colleagues to Talamanca. When I was back in March 2019, Elías immediately mentioned everyone by name and asked how they were doing. So did Heidi and Alejandro and several others. They also asked me what we were doing with all the information we had requested.

\section{INREL in Sápmi, Nagaland, and Hawai'i}

The INREL project has, over five years, regularly brought together the authors of the present book in what have certainly been educative encounters with indigeneities. On our first field site workshop, in Sápmi, in April 2016, we followed roughly the same route that Alejandro, Justo, Carlos, Sandra, Monica, and I had taken half a year earlier, but, interestingly, we got quite different receptions at the Sámi institutions in Guovdageaidnu and Kárášjohka. We were met with more reservation. Was it because we were a uniform party of non-indigenous scholars on an overt mission to study indigenous religion? In September 2017, I did a similar tour with Geyner Blanco, a Maleku leader and the first Costa Rican government advisor on indigenous affairs, and William Vega, a Costa Rican human rights lawyer, whom I had invited to Tromsø for a workshop about consultations with indigenous peoples, ${ }^{41}$ and, in March 2018, Siv Ellen and I took Arkotong, since he had been unable to attend the first INREL workshop (cf. Longkumer, Chapter 3). On these two later occasions, we again got more intimate and hearty treatment. Going with someone who gets recognised as indigenous - Alejandro, Justo, Geyner, or Arkotong - makes a difference. Maybe it also mattered that we asked much less about religion during these other visits?

In Nagaland, in December 2016, for our second field site workshop, Arkotong introduced us to members of a local intelligentsia and an indigeneity marked 
by statehood, territoriality, a fight for sovereignty, Christianity, kinship, languages, cuisine, and emblematic artefacts (shawls, spears, knifes, and necklaces) that were presented as 'from the past'. The evidence of educative efforts were everywhere: in the staged performances of 'past times' and 'past practices' at the Hornbill Festival in Kohima, attended by government officials and other dignitaries, tourists from near and afar, and locals of all ages (cf. Longkumer 2015, 2016); in the research and outreach activities of the Kohima Institute, including the annual Hutton lecture, this year given by Siv Ellen on the situation at Standing Rock; in the museological exhibitions of huge log drums and morungs (traditional houses of learning) at central locations in each Naga village; in the churches that loom large in the landscape, many of them with schools and missionary stations in their compounds; in sculptural woodcarvings that, according to the artist and villagers, awakened old spirits (cf. Longkumer 2018); in the various monuments commemorating heroes of the sovereignty struggles; and in an impressive flora of road signs with Christian proverbs, not to forget the massive Christmas decorations that made it impossible to ignore that, to many of its inhabitants, this is a promised land religiously as well as politically. The aesthetics of all these public educational endeavours addressed and made tactile a tension between old times and new times, old religion and new religion, coloniality and sovereignty, violence and community. But what were the loci of indigenous religion here? Was it the things that were treated as 'from the past'? Was it Baptist Christianity? I went home thinking it had to be both, plus the relations between them, including the tensions. Or, perhaps especially the tensions?

Of course, Arkotong's mediation, his pedagogical translations of all these multifaceted translations, was crucial in order for us to grasp a little bit more than just the immediate surface of things. He also took us beyond the public square and into the private spheres of some of his relatives and friends, where we were shown tremendous hospitality and where we got small but closer glimpses of how life can unfold in different parts of Nagaland, experiences that made our learning more personal and emotional. By taking us home to where he had grown up, he, whom we already knew as the ultra-cosmopolitan critical scholar from the University of Edinburgh, illustrated, in propria persona, the immense scale that indigeneity can take in one individual. He exposed how local grounds are made up of multiple smaller units - villages, clans, neighbours, friends, families, households, and individuals (cf. Alles, Chapter 4) - but also how globality may be conveyed in one person.

The final field site workshop of INREL, organised by Greg Johnson on Hawai'i in July 2018, half a year after our visit in Talamanca, centred on a Hawaiian protest and revitalisation movement spurred by the planned construction of a gigantic astronomical telescope on Mauna Kea, the tallest mountain in the Pacific Ocean. We quickly learnt that the main leaders of this movement are teachers and scholars. They inspire and educate young people, some of whom, when the conflict has escalated, have risen to the occasion and become leaders themselves. The exhibition in the Hawaiian Cultural Center of Hāmākua (cf. Johnson, Chapter 5), where we had some of our workshop meetings, was all about 
educating the public, including us, about Hawaiian traditions and responsibilities. Facebook - or 'Sacred Facebook' as one of the movement leaders named it - was another important tool for outreach and learning for this community of 'protectors of the Mauna'. Facebook enabled educative exchanges with the larger Hawaiian community, with Native Americans from continental United States, and with actors in international indigenous peoples' movements elsewhere. The museum, Facebook, and the mountain where the most direct protest actions have taken place have become spaces for developing and sharing narratives that differ from the official ones promulgated by the state, spaces where indigeneity and claims of sacredness are articulated in opposition to state perspectives and practices - and, indeed, in opposition to some international scientific perspectives and practices. In and from these spaces, people are taught to see behind and beyond colonial structures, and to start imagining how a sovereign Hawai'i could be rebuilt after more than a hundred years of American dominance.

The Mauna Kea conflict involves scholars on both sides: astronomers and physicists versus indigenous educators and historians, all of them allied with colleagues around the world. Becoming involved temporarily in one of these alliances, via Greg Johnson, was a reminder of how crucial it is to manoeuvre empathetically as a scholar in order to maximise learning and earn the trust that enables more nuanced insights and analyses, and of how inevitable it is that we become personally entangled in the projects of people with whom we work over many years. As in all the previous workshops, it was conspicuous how the relations and the focus of the scholar organising the visit steered us. While we concentrated our attention on a movement which, besides being deeply rooted in Hawaiian traditions, was clearly inspired by New Age, signs of Christianity, churches for example, could be seen everywhere along the roads around the island, but, during the entire week, we never interacted with anything that had the slightest Christian flavour. We spent our time with one distinctive religious movement within a larger and largely Christian indigenous community.

Something similar happened during our workshop in Talamanca. We did not visit any of the churches or talk to any of the Christian leaders there either, even if they represent a large religious majority. Some of us talked about Talamancan Christianities, in particular during our drives, commenting on different churches as we passed them, but in the process of writing this book, I have discovered that some of my colleagues, especially those who rode mostly in our second car, went home with the impression that most Bribris are Bahá'í.

\section{Critical reflections on encounters with indigenous religions}

Partial views are all we get, but we can work hard to expand our outlook. Our entry to a new space and how we later move in the terrain, conceptually as well as physically, is decisive for what we learn and what we as scholars end up producing based on the encounters we take part in. The episodes described in this chapter have all altered how I move in Talamanca, Tromsø, and elsewhere. The INREL 
project has broadened my conceptual and geographical horizons, encouraged me to extend my research far beyond Talamanca proper, and prompted me to rethink much of what I have done previously in Talamanca and Tromsø. It has made me ask new questions, use new methods, and theorise differently.

'Indigenous religion(s)' has been the conceptual baseline of INREL, and served both as a theoretical starting point and an empirical end. It has been at once a method and a predetermined finding of our joint endeavours. We have, through the commoning that we have performed (cf. Blaser and de la Cadena 2017, 2018), pedagogically, politically, and analytically, contributed to constituting a subject or an entity, a domain, and a scale of vast complexity and scope that have actualised indigenous religion(s) in the different contexts where we have worked. However, the concept was not invented with INREL. There were subjects or entities, domains, and scales, not to forget methods, of indigenous religion (in the singular) and indigenous religions (in the plural) circulating in both academic (cf. Chidester 2014; Cox 2007; Geertz 2004; Gill 2018) and nonacademic worlds long before our project was conceived. The co-constituting of indigenous religions that we have been involved in has happened in encounters with different actors who articulate and actualise indigenous religions, who common or uncommon them, in divergent ways.

The uncommoning of indigenous religions has been a longstanding concern of mine (cf. Tafjord 2013, 2016b, 2017), and this has become both more difficult and easier through INREL. ${ }^{42}$ It has become more difficult because the title of the project, its method, its subject, its conversations, its publications, and most of its other output encourage our collaborators and audiences to associate anyone and anything we address with indigenous religion(s). INREL more than suggests that Talamancans have an indigenous religion, since Talamanca is included as one of the sites we study, and if people do not take a closer look at what we write, they will probably not think that we are talking about the Bahá'i Faith. Yet, those who do take a closer look might become puzzled by some Bribris' clear articulation of the Bahá'í Faith as their indigenous religion, and by other INREL examples which question received academic wisdom of what an indigenous religion may be. The INREL project has generated several surprises of this and other kinds, and thus made it easier for all its collaborators to uncommon indigenous religion(s).

Nevertheless, as scholarship hits the ground and affects people's politics, unintended 'siding effects' are hard to control (Tafjord 2016b). While we waited for the boats on the river bank in Bratsi, and the rest of the INREL group was busy with other discussions, Alejandro Swaby told me he had read the essay that I had written and sent him some time ago, titled "How Talking about Indigenous Religion May Change Things: An Example from Talamanca” (Tafjord 2016a). He said I had gotten it all right, except one important issue: those who talk about an indigenous religion among the Bribri are wrong. He asserted that such a thing had never existed here and that these ideas were the result of misunderstandings and a lack of proper knowledge of the indigenous histories and practices. 
Gently but firmly he indicated that I, too, was wrong, since I, in my essay, do not univocally endorse the position of the elders, like himself, who refute the translation of traditional Bribri knowledge and practices into 'indigenous religion'. In it, I also acknowledge how a younger generation of Bribri university students, politicians, educators, and tourist guides have begun to perform this translation in encounters and in tune with scholars, lawyers, doctors, journalists, environmentalists, tourists, and missionaries from outside. As the boats arrived and Alejandro invited us aboard, I could not help but feel ambivalent, again, about having brought a whole group of foreign scholars to look for indigenous religion in his community.

For me, all the encounters I describe in this chapter have had extraordinary educative effects. By sharing them I hope to contribute to an accumulation of examples that teach us more about how translations and comparisons are pedagogical, political, and analytical moves that everyone makes - moves that must be made to manifest indigeneity and indigenous religions, whether as commons or uncommons, either on local grounds or through globalising networks. The particularities with which such translations and comparisons are done, and the particularities that such translations and comparisons produce, vary immensely. It is critical to keep in mind that they can always be translated and compared differently.

\section{Notes}

1 Thanks to everyone who has taught me things that now resound in this chapter. The support from Elías Escalante, Alejandro Swaby, Heidi Mayorga, Justo Avelino Torres Layan, and their families and communities in Talamanca has been invaluable. Carlos Borge and Sandra Esquivel have also helped and encouraged me continuously in Costa Rica. Monica Grini and Siv Ellen Kraft have been vital in Tromsø over many years. Collaborations and conversations with Arkotong Longkumer, Greg Alles, Rosalind Hackett, Greg Johnson, Afe Adogame, May-Lisbeth Brew, Liudmila Nikanorova, Helen Jennings, Aheli Moitra, and other INREL associates have expanded my horizons and improved this chapter. In addition to the generous resources granted by UiT The Arctic University of Norway and the Research Council of Norway, this chapter owes credit to Leipzig University's Humanities Centre for Advanced Studies and the project "Multiple Secularities - Beyond the West, Beyond Modernities", and to the Centre for Advanced Study at the Norwegian Academy of Science and Letters and the project "The Body in Translation".

2 For a general presentation of INREL, see this book's Introduction.

3 About encounters as generators of creativity, see Gill (2018) and Clifford (2013).

4 As methods, indigeneity and indigenous religion can of course be used in other ways, too, for example aesthetically, economically, or theologically. Cf. Tafjord (2018a).

5 For another perspective on translation as a basic move that everyone makes and the work it does, see Hanks and Severi (2014).

6 Between 1993 and 1999 I lived in Costa Rica periodically, in total for about three years, but I had never been to Talamanca before the autumn of the year 2000, when I went there hoping to do fieldwork for my dissertation. The decision to go to Talamanca was largely triggered by disbelief in a myth I had met while attending high school in Ciudad Quesada, a settler town in the northern part of the country. Our teachers in history and social sciences told us that there had never been many indigenous peoples in Costa Rica 
and that presently there were none. By teaching us this, they were reproducing a national myth that has been hegemonic in public discourses about Costa Rica for more than a century (Díaz-Azofeifa 2012; Soto 2008). It was books written by the anthropologists María Eugenia Bozzoli (1979) and Marcos Guevara (1993) that first made me aware of the Bribri in Talamanca, and it was the anthropologist Carlos Borge who first brought me there and introduced me to his collaborators and friends, most importantly the community leader Rosendo Jackson and his son Elías Escalante.

7 This claim was often made with reference to a letter, originally titled "Message to the Indian and Eskimo Bahá'is of the Western Hemisphere", written (in 1969, to the National Spiritual Assembly of the Bahá'ís of Canada) by Amatu'l-Bahá (or Rúhíyyih Khánum, or Mary Maxwell), a prominent Bahá'í leader. See https://bahai-library.com/ khanum_message_indian_eskimo, last accessed 30 October 2018. A Spanish translation of this letter circulated in Barrio Escalante.

8 On the history of the Bahá'i Faith, see for example Warburg (2006).

9 For different versions of this history (Bribris insist that it is history, not a myth or a legend), see for example Bozzoli (1979) and Jara and García (1997).

10 With the United Fruit Company came also the first Protestant churches (Baptists and Adventists), but they catered primarily to the African-American workers (Bourgois 1994).

11 The Costa Rican Indigenous Act is available online through the Sistema Costarricense de Información Jurídica of the Procuraduría General de la República, see www.pgrweb. go.cr/scij/Busqueda/Normativa/Normas/nrm_texto_completo.aspx?param1=NRTC \&nValor1 $=1 \&$ nValor2=38110\&nValor3=66993\&strTipM $=$ TC

12 I did fieldwork in Talamanca in 2000, 2001, 2007, 2009, 2013, 2014, 2015, 2016, 2017, 2018, and 2019.

13 Thanks to Yorleny Blanco, Alejandro Rodríguez, and Alejandro Swaby for supporting and thus making possible this consultation.

14 This is how I primarily understand 'indigenous methodologies': as local protocols for research, usually taught to the researcher by the people with whom the researcher collaborates. Books and articles written by academics who are indigenous to communities elsewhere can of course inspire and create more critical reflection about such protocols and learning processes (for example, for me, Linda Tuhiwai Smith's Decolonizing Methodologies [1999] has been formative), but they can never replace what the researcher must learn from the people with whom (s)he actually studies.

15 In our conversations he would sometimes mention Adolfo Constenla, Alvaro Dobles, Carlos Borge, and Laura Cervantes.

16 For some of these histories, see Bozzoli (1979) and Jara and García (1997).

17 We have been to Isla Chira on the west coast of Costa Rica to interview the first Bahá'í pioneer who came to Talamanca, and we have been to Soloy in Panama to meet with Bahá'ís among the Ngäbe (see Tafjord 2004).

18 Elías has, for example, taught me how to wait properly, which is crucial in Talamanca. For a description and methodological reflections on this, see Tafjord (2018b).

19 This includes texts. In 2007 and 2009, when I returned with translations of parts of my dissertation (what I had learnt mainly in Spanish had been written about in Norwegian and now I had translated most of my text back into Spanish), Elías was instrumental in deciding the procedure for sharing and discussing these with individuals and the community. See Tafjord (2007).

20 Elías is her maternal uncle.

21 For several alternative uses of indigeneity, see Canessa (2018). For several alternative uses of indigenous religion, see Tafjord (2017).

22 By law, Sámis have become distinguished from other Norwegians both as a different people and as a different kind of people. Since 1998, they are also distinguished from "national minorities" in Norway: Forest Finns, Jews, Kvens, Roma, and Romani (see www.regjeringen.no/no/tema/urfolk-og-minoriteter/nasjonale-minoriteter/id1404/). Sámi politicians have insisted that they, as an urfolk or an indigenous people, should have 
a different status and other rights than the national minorities. These distinctions also influence research (cf. Niemi 2002; Niemi and Semb 2009).

23 See, for example, the outcome document from the Global Indigenous Preparatory Conference organised in Alta in 2013, for the United Nations World Conference on Indigenous Peoples in New York in 2014: www.un.org/esa/socdev/unpfii/documents/wc/ AdoptedAlta_outcomedoc_EN.pdf (accessed 1 November 2019).

24 See https://en.uit.no/om/enhet/omoss?p_dimension_id=88182 and https://uit.no/ utdanning/program?p_document_id=270446 (accessed 1 November 2019). I have supervised three master's dissertations in this programme and contributed with single lectures to the methodology course. About ten students enrolled in this programme have taken my graduate course called "Anthropological Approaches in the Study of Religions".

25 See https://uit.no/om/enhet/aktuelt/nyhet?p_document_id=573781\&p_dimension_ $\mathrm{id}=88182$ (accessed 1 June 2019), and more recently https://uit.no/om/enhet/aktuelt/ nyhet?p_document_id=629948\&p_dimension_id=88182 (accessed 13 June 2019)

26 About $71 \%$ of Norwegian citizens are members of the Church of Norway (see https:// kirken.no/nb-NO/om-kirken/bakgrunn/om-kirkestatistikk/medlemsstatistikk/).

27 The annual festival Isogaisa is perhaps the largest public venue for Sámi shamanism today, see http://isogaisa.org/en/. For information about Sámi issues in the Church of Norway, see https://kirken.no/nb-NO/om-kirken/slik-styres-kirken/Sámisk-kirkeliv/.

28 The purported secular public domain of Norway is extended over Sámi territories as well, at least institutionally, for example in the field of law (cf. Årsheim 2018). Nonetheless, as far as I know, secularism and secularity in Sápmi are topics that have not yet been studied properly.

29 INREL has necessarily promoted the idea that indigenous peoples have indigenous religions, even if some of us are troubled by this (cf. Tafjord 2013). In anthropology, the so-called ontological turn (cf. Holbraad and Pedersen 2017) has made theories about animism fashionable again and brought new attention to indigenous peoples' knowledges and practices, often in ways that spiritualise or religionise them.

30 Nowadays Bribris are much more exposed to aggressive missionising than Sámis. Talamanca attracts Christian missionaries from multiple churches and movements, many of them with substantial backing from abroad.

31 In the years between her two visits to Tromsø, we have met several times in Costa Rica, usually in San José where her home functions almost like an embassy for Bribris in the capital city. There she has been a major encourager of the emerging indigenous student movement. Her international horizon, network, and the topics she is interested in have also widened because of her Chilean husband who is a historian and environmentalist. San José is a hub for international NGOs of different kinds and hosts institutions like the Inter-American Court of Human Rights.

32 She and her family in Talamanca are Bahá'ís.

33 On Costa Rica's international image, see for example Boukhris (2012).

34 This was made possible with funds from the Norwegian Latin America Research Network.

35 For more about these institutions, see their webpages: https://samas.no/en, https:// www.sametinget.no/Om-Sametinget/About-the-Sami-Parliament, www.nrk.no/sapmi/ om/1._about-nrk-sapmi-1.11296850, https://rdm.no/english/ (accessed 24 October, 2019).

36 His son, Guillermo Rodríguez, also has a lifelong career as a leader in Talamanca Bribri and in movements and organisations of indigenas in Costa Rica and internationally. In 2017, he became the first Bribri to graduate from law school, and, in 2018, he was appointed ambassador to Bolivia by the Costa Rican government as the hitherto only indigena to ever hold such a post on behalf of this country. In Talamanca, this appointment raised hopes of increased international collaboration between indigenas.

37 When we visited the Sámi Parliament, we all regretted that its elected members were not there to personally receive the greeting Alejandro had prepared for them. But Alejandro expressed his sympathy with the need for indigenous politicians to be travelling, both to 
engage in the activities of their own communities, and to negotiate with allies as well as adversaries at home and abroad.

38 This development project has organised courses in 'moral leadership'. It has also distributed small solar panels to households without electricity.

39 For more about the ditsöwö, see Bozzoli (1979) and Jara and García (1997).

40 A point previously made by Borge and Villalobos (1994) and Borge and Castillo (1997).

41 For information about the government mechanism for consultations with indigenous peoples in Costa Rica that Geyner and William were setting up, see www. consultaindigena.go.cr/ (accessed 2 November 2019).

42 The most fruitful scholarly contributions to the uncommoning of indigenous religions are, in my opinion, Johnson (2002) and de la Cadena (2018).

\section{References}

Blaser, Mario and Marisol de la Cadena. 2017. "The Uncommons: An Introduction". Anthropologica 59 (2): 185-193.

Blaser, Mario and Marisol de la Cadena. 2018. A World of Many Worlds. Durham, NC: Duke University Press.

Borge, Carlos. 2012. Situación de los docentes en territorios indígenas de Costa Rica. San José: UNICEF.

Borge, Carlos and Roberto Castillo. 1997. Cultura y conservación en la Talamanca indígena. San José: EUNED.

Borge, Carlos and Victoria Villalobos. 1994. Talamanca en la encrucijada. San José: EUNED.

Boukhris, Linda. 2012. "L'imaginaire touristique à l'épreuve du Costa Rica: entre 'voir' et 'faire' le territoire". Via 1 https://journals.openedition.org/viatourism/ 1212\#quotation

Bourgois, Philippe. 1994 (1989). Banano, etnia y lucha social en Centro América. San José: DEI.

Boza Villareal, Alejandra. 2014. La frontera indígena de la Gran Talamanca 1840-1930. San José: EUCR-EUNED.

Bozzoli, María E. 1979. El nacimiento y la muerte entre los bribris. San José: Editorial Universidad de Costa Rica.

Bozzoli, María E. 2006. Oí decir del Usékar. San José: EUNED.

Canessa, Andrew. 2018. "Indigenous Conflict in Bolivia Explored through an African Lens: Towards a Comparative Analysis of Indigeneity". Comparative Studies in Society and History 60 (2): 308-337.

Cervantes Gamboa, Laura. 2003. Sounds Like Music: Ritual Speech Events among the Bribri Indians of Costa Rica. Doctoral dissertation. University of Texas at Austin.

Chidester, David. 2014. Empire of Religion: Imperialism and Comparative Religion. Chicago: University of Chicago Press.

Clifford, James. 2013. Returns: Becoming Indigenous in the Twenty-First Century. Cambridge, MA: Harvard University Press.

Cox, James L. 2007. From Primitive to Indigenous: The Academic Study of Indigenous Religions. Aldershot: Ashgate.

Cox, James L. 2016. "Kinship and Location: In Defense of a Narrow Definition of Indigenous Religions”. In Religious Categories and the Construction of the Indigenous, edited by Christopher Hartney and Daniel J. Tower. Leiden: Brill, 38-57.

de la Cadena, Marisol. 2015. Earth Beings: Ecologies of Practice across Andean Worlds. Durham, NC: Duke University Press.

de la Cadena, Marisol. 2018. "Earth-Beings: Andean Indigenous Religion but Not Only". In The World Multiple: The Quotidian Politics of Knowing and Generating Entangled 
Worlds, edited by Keiichi Omura, Grant. J. Otsuki, Shiho Satsuka, and Atsuro Morita. London: Routledge. https://doi.org/10.4324/9780429456725

Díaz-Azofeifa, Gisella. 2012. "Paradoxes of Costa Rican Multiculturalism”. Latin American and Caribbean Ethnic Studies 7 (2): 137-154.

Drüg, Bernardo. 1995. Historia de la viceprovincia de Costa Rica. Teruel: Ediciones Fe y Vida.

Falch, Torvald and Per Selle. 2018. Sametinget: institusjonalisering av en ny samepolitikk. Oslo: Gyldendal.

Fonneland, Trude. 2017. Contemporary Shamanisms in Norway: Religion, Entrepreneurship, and Politics. Oxford: Oxford University Press.

Geertz, Armin W. 2004. "Can We Move beyond Primitivism? On Recovering the Indigenes of Indigenous Religions in the Academic Study of Religion". In Beyond Primitivism: Indigenous Religious Traditions and Modernity, edited by Jacob K. Olupona. New York: Routledge, 37-70.

Gill, Sam. 2018. Creative Encounters, Appreciating Difference: Perspectives and Strategies. Lanham: Lexington Books.

Grini, Monica. 2016. Samisk kunst i nork kunsthistorie: historiografiske riss. Doctoral dissertation. UiT The Arctic University of Norway.

Guevara Berger, Marcos. 1993. "A Visit to a Bribri Shaman". In South and Meso-American Native Spirituality: From the Cult of the Feathered Serpent to the Theology of Liberation, edited by Gary. H. Gossen and Miguel León-Portilla. New York: Crossroad, 371-390.

Hanks, William F. and Carlo Severi (eds.). 2014. Special Issue: "Translating Worlds: The Epistemological Space of Translation". HAU: Journal of Ethnographic Theory 4 (2).

Holbraad, Martin and Morten Axel Pedersen. 2017. The Ontological Turn: An Anthropological Exposition. Cambridge: Cambridge University Press.

Jara Murillo, Carla V. and Alí García Segura. 1997. Kó késka: El lugar del tiempo: Historias $y$ otras tradiciones orales del pueblo bribri. San José: Editorial de la Universidad de Costa Rica.

Johnson, Greg and Siv Ellen Kraft. 2018. "Standing Rock Religion(s): Ceremonies, Social Media, and Music Videos". Numen 65 (5-6): 499-530.

Johnson, Paul C. 2002. "Migrating Bodies, Circulating Signs: Brazilian Candomblé, the Garifuna of the Caribbean, and the Category of Indigenous Religions". History of Religions 41 (4): 301-327.

Kraft, Siv Ellen. 2015. "Sámi Neo-Shamanism in Norway: Colonial Grounds, Ethnic Revival and Pagan Pathways". In Contemporary Pagan and Native Faith Movements in Europe: Colonialist and Nationalist Impulses, edited by Kathryn Rountree. New York: Berghahn, 25-43.

Kraft, Siv Ellen. 2017. “U.N.-Discourses on Indigenous Religion”. In Handbook of Indigenous Religion(s), edited by Greg Johnson and Siv Ellen Kraft. Leiden: Brill, 80-91.

Kraft, Siv Ellen, Trude Fonneland, and James R. Lewis (eds.). 2015. Nordic Neoshamanisms. New York: Palgrave Macmillan.

Longkumer, Arkotong. 2015. “'As Our Ancestors Once Lived': Representation, Performance and Constructing a National Culture amongst the Nagas of India". Himalaya 35 (1): 51-64.

Longkumer, Arkotong. 2016. "Visualising National Life: The Hornbill Festival as Culture and Politics". In Focus on World Festivals: Contemporary Case Studies and Perspectives, edited by Chris Newbold and Jennie Jordan. London: Goodfellow Publs.

Longkumer, Arkotong. 2018. "Spirits in a Material World: Mediation and Revitalization of Woodcarvings in a Naga Village". Numen 65 (5-6): 467-498. 
Minde, Henry. 1996. “The Making of an International Movement of Indigenous Peoples". Scandinavian Journal of History 21 (3): 221-246.

Minde, Henry. 2003. "Assimilation of the Sami: Implementation and Consequences". Acta Borealia 20 (2): 121-146.

Minde, Henry. 2008. "The Destination and the Journey: Indigenous Peoples and the United Nations from the 1960s through 1985”. In Indigenous Peoples: Self-Determination, Knowledge, Indigeneity, edited by Henry Minde. Delft: Eburon, 49-86.

Niemi, Einar. 2002. "Kategorienes etikk og minoritetene i nord: et historisk perspektiv". In Samisk forkking og forskningsetikk. Oslo: Forskningsetiske komiteer, 22-44.

Niemi, Einar and Anne Julie Semb. 2009. "Forskningsetisk kontekst: historisk urett og forskning som overgrep". De nasjonale forskningsetiske komiteene. www.etikkom. no/FBIB/Temaer/Forskning-pa-bestemte-grupper/Etniske-grupper/Forskningsetiskkontekst-Historisk-urett-og-forskning-som-overgrep/

Rojas Conejo, Daniel. 2009. Dilema e identidad del pueblo bribri. San José: Editorial de la Universidad de Costa Rica.

Rydving, Håkan. 1995 (1993). The End of Drum-Time: Religious Change among the Lule Saami, 1670s-1740s. Stockholm: Almqvist \& Wiksell.

Rydving, Håkan. 2010. Tracing Sami Traditions: In Search of the Indigenous Religion among the Western Sami during the 17th and the 18th Centuries. Oslo: Novus.

Smith, Linda Tuhiwai. 1999. Decolonizing Methodologies: Research and Indigenous Peoples. London: Zed Books.

Solórzano, Fonseca and Juan Carlos. 2013. Los indígenas en la frontera de la colonización: Costa Rica 1502-1930. San José: EUNED.

Soto Quirós, Ronald. 2008. "Imaginando una nación de raza blanca en Costa Rica: 1821-1914”. Amérique Latine: Historie et Mémoire 15. https://journals.openedition.org/ alhim/2930

Tafjord, Bjørn Ola. 2004. Ritualiserte forståingar: bribriar og bahá'í-trua. Doctoral dissertation. University of Bergen.

Tafjord, Bjørn Ola. 2006. "Defining Religion, Defying Tradition? Concord and Conflict about the Role of Religion in a Costa Rican Indigenous Community". In Exercising Power: The Role of Religions in Concord and Conflict, edited by Tore Ahlbäck. Åbo: Donner Institute for Research in Religious and Cultural History, 374-392.

Tafjord, Bjørn Ola. 2007. "Om heimlege metodologiar: lærdommar frå forsking med bribriar”. Din: tidsskrift for religion og kultur 1: 31-51.

Tafjord, Bjørn Ola. 2013. "Indigenous Religion(s) as an Analytical Category". Method and Theory in the Study of Religion 25 (3): 221-243.

Tafjord, Bjørn Ola. 2016a. "How Talking about Indigenous Religion May Change Things: An Example from Talamanca". Numen 63 (5-6): 548-575.

Tafjord, Bjørn Ola. 2016b. "Scales, Translations and Siding Effects: Uses of indígena and religión in Talamanca and Beyond". In Religious Categories and the Construction of the Indigenous, edited by Christopher Hartney and Daniel J. Tower. Leiden: Brill, 138-177.

Tafjord, Bjørn Ola. 2017. "Towards a Typology of Academic Uses of 'Indigenous Religion(s)', or Eight (or Nine) Language Games That Scholars Play with This Phrase". In Handbook of Indigenous Religion(s), edited by Greg Johnson and Siv Ellen Kraft. Leiden: Brill, 25-51.

Tafjord, Bjørn Ola. 2018a. "Modes of Indigenizing: Remarks on Indigenous Religion as a Method". International Journal for the Study of New Religions 9 (2): 303-327. 


\section{Bjørn Ola Tafjord}

Tafjord, Bjørn Ola. 2018b. "Venting som metode". Dīn: tidsskrift for religion og kultur 2: $158-165$.

Viveiros de Castro, Eduardo. 2004. "Perspectival Anthropology and the Method of Controlled Equivocation". Tipití: Journal of the Society for the Anthropology of Lowland South America 2 (1): 3-22.

Warburg, Margit. 2006. Citizens of the World: A History and Sociology of the Baha'is from a Globalisation Perspective. Leiden: Brill.

Årsheim, Helge. 2018. "Including and Excluding Indigenous Religion through Law". Numen 65 (5-6): 531-561. 